Document downloaded from:

http://hdl.handle.net/10251/122235

This paper must be cited as:

Marqués Pérez, I.; Segura García Del Río, B. (2018). Integrating social preferences analysis for multifunctional peri-urban farming in planning. An application by multi-criteria analysis techniques and stakeholders. Agroecology and Sustainable Food Systems. 42(9):10291057. https://doi.org/10.1080/21683565.2018.1468379

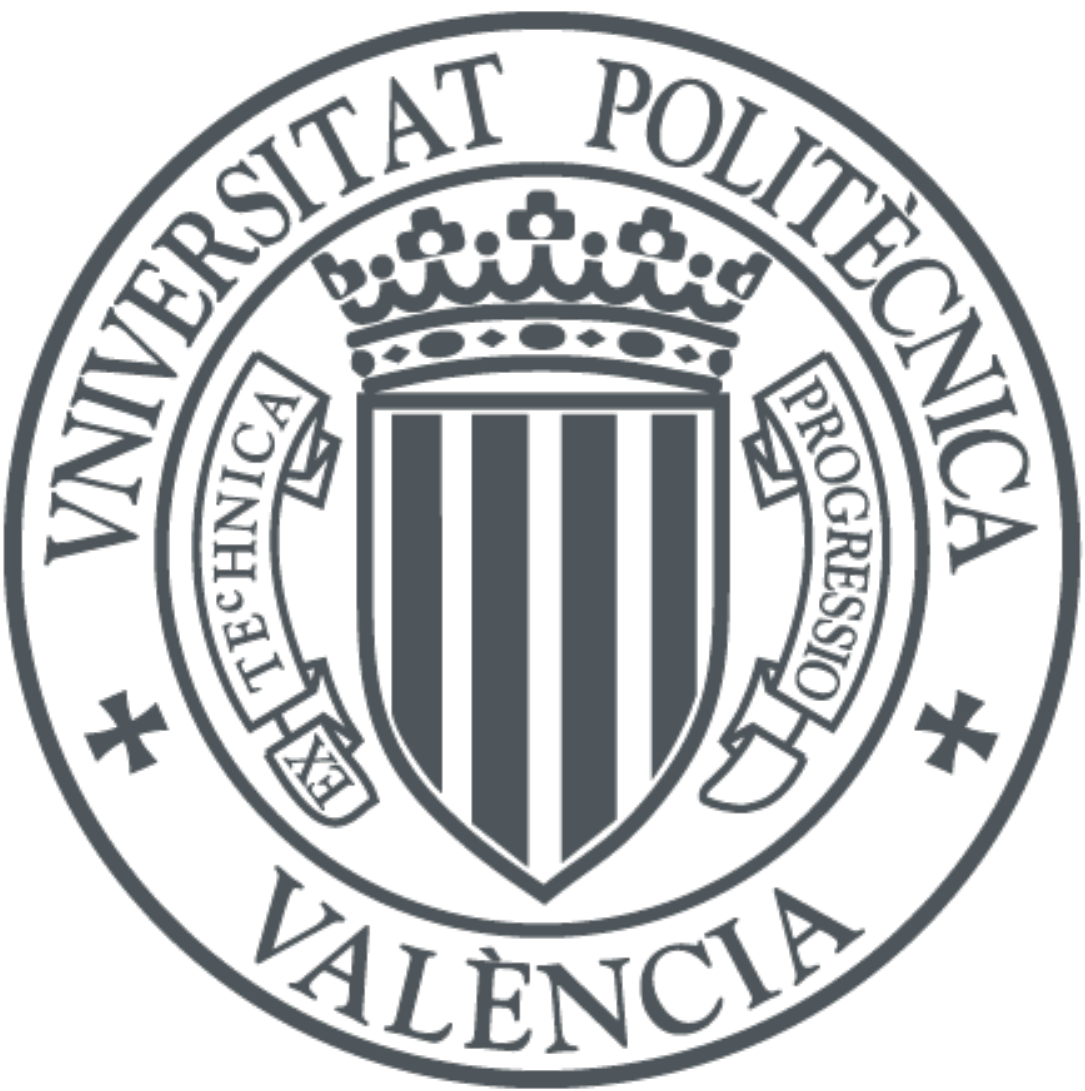

The final publication is available at

https://doi.org/10.1080/21683565.2018.1468379

Copyright Taylor \& Francis

Additional Information 


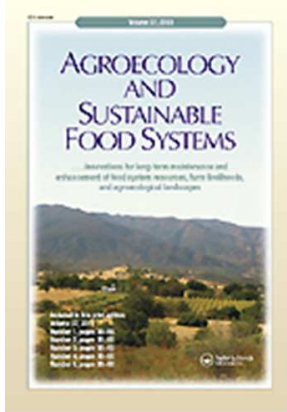

\section{Integrating social preferences analysis for multifunctional peri-urban farming in planning. An application by multi- criteria analysis techniques and stakeholders.}

\begin{tabular}{|r|l|}
\hline Journal: & Agroecology and Sustainable Food Systems \\
\hline Manuscript ID & WJSA-2017-0183.R1 \\
\hline Manuscript Type: & Review \\
\hline Keywords: & $\begin{array}{l}\text { Agricultural systems, peri-urban agriculture, public goods, social optimum, } \\
\text { multicriteria analysis methodologies }\end{array}$ \\
\hline
\end{tabular}

\section{SCHOLARONE ${ }^{\text {m }}$ \\ Manuscripts}




\footnotetext{
${ }^{1}$ Urban fringe is the transition zone between the consolidated part of cities and the agricultural land.
} suburbs, generally containing land that is valuable for agricultural production. There are, nonetheless, several factors which threaten the viability of these farms and their productive activity,-like-market pressures, changes in consumption patterns, the weakness of the productive sector in negotiations with

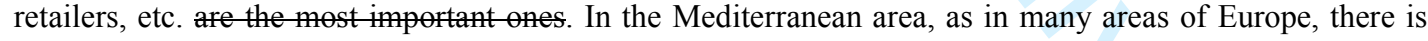
also pressure for alternative and theoretically more profitable land use,-with farming now having to compete on the land market with other non-agricultural land uses, such as housing. The price for a piece of farmland in this area can rise dramatically and $T$ there are incentives for farmers to sell land for urban development purposes (Elhadary, Samat and Obeng-Odoom 2013; Vaz, De Nohornha and Nijkamp 2014; Zasada 2011). However, peri-urban agricultural systems are also valuable as an important cultural, natural and landscape heritage (van Zanten et al. 2014; Zasada 2011). In some urban fringes ${ }^{1}$, agriculture and anthropological elements (rural, civil and hydraulic architecture) have been combined harmoniously to create a rich landscape shaped by human intervention. Indeed, these open green peri-urban spaces have become 
increasingly important in the green infrastructures of cities. Recently, urbanites have opened up a new field of debate, and urban agriculture has been discussed more in terms of production quality, production quantity and food security in urban areas, as well as in terms of new business models and (social) entrepreneurship which generate new market options. Consumers trust the quality and safety of proximity food produced using environmentally-friendly techniques, which is purchased through relatively short channels and often acquired directly from farmers (Filippini et al. 2016; Mincyte and Dobernig 2016; Opitz et al. 2016). Helping to improve the income level of farmers and build the community are considered, ultimately, the main factors for maintaining the landscape and territory. As a result of the changing perception of society, land in urban fringes has increased its value on account of its capacity to provide public goods and services ${ }^{2}$ relating to leisure and recreation (Figure 1), as well as the preservation and conservation of the environment, and the provision of safe and healthy food.

Figure 1: Proposals for the recreational use of the Huerta de Valencia

Urban planning has to take into account public preferences for the functions, and goods and services that these urban fringes can provide, and then include these results in the decision-making process of urban growth strategies versus the conservation and preservation of farmland. The support for peri-urban agricultural areas requires not only good urban planning, but also coordinated action between urban planning, the public health system, and environmental resources management (Fernández et al. 2013; García Álvarez-Coque and López-García 2011). On the other hand, the joint production ${ }^{3}$ of public and private goods by agriculture requires that these actions are integrated into the agricultural planning of periurban areas. Therefore, policies should be designed that guide the decisions of farmers, leading to agrosystems with agriculture activity which performs the necessary functions and provides the goods and services demanded by society.

All of this requires a detailed analysis of the functions that a peri-urban agricultural system can perform. The Multifunctionality concept provides an integrated view of the agrosystems, encompassing all the functions, goods and services that can be developed, grouping them into different dimensions: economic, social and environmental. The most recent interpretations of this concept form the basis of an approach seeking to legitimise public intervention in the interests of conserving agricultural systems which can assume complementary roles in the production of food and raw materials (Abler 2001; Ahtiainen et al. 2015; Kallas, Rodríguez, and Hurlé 2007; Madureira, Rambonilaza, and Karpinski 2007; Marqués-Pérez and Segura 2016; Reig 2007; Renting et al. 2009).

In addition, it is essential to know the social preferences for the functions, and goods and services of the agrosystem. There are many studies on the demand for goods and services provided by agriculture:

\footnotetext{
${ }^{2}$ Public goods are goods or services that provide utility to society and which meet the principles of non-rivalry and non-exclusion There are no property rights over these goods and services, and consumption by one or more individuals does not compete with the consumption of the same good by other consumers.

${ }^{3}$ Public goods and services are generated simultaneously through the production of food and raw materials. Although agricultural activity seeks market economic benefits with the exchange of food and raw materials, environmental and social goods are public goods without markets where they can be exchanged for rents.
} 
2

1 for example, Dehnhardt and Meyerhoff (2002) on the biodiversity in the floodplains of the river Elbe; 2 Schmitz, Schmitz, and Wronka (2003) and Sayadi, González, and Calatrava-Requena (2004) on agricultural 3 landscapes; Lamptey, Barron, and Pollard (2005) on the influence of agriculture on urban climate;

${ }^{4}$ This scale is theoretically justified and its effectiveness has been empirically validated (Martínez 2007; Dong et al. 2008; (Koczkodaj, Kulakowski, and Ligeza 2014). AHP (Analytic Hierarchy Process) is a methodology introduced by Saaty (1977) based on pairwise comparisons, with a particular fixed ratio scale, to create a numerical ranking in the process of comparison ${ }^{4}$. The numerical ranking converts the AHP in a subset of PC methodology. This methodology has been increasingly applied in the research fields of agriculture and the environment in recent years. The preference for this methodology is explained by the large number of criteria to be considered in order to determine the social optimum, which requires quite a complex utility function. In contrast, the application of the AHP is less problematic to develop and provides solutions which can be interpreted and validated in terms of utility functions (Duke and Aull-Hyde 2002; Dinc, Hayness, and Tarimcilar 2003; Kangas and Leskinen 2005; Ananda and Herath 2008; Cai and Shang 2009; Gómez-Navarro et al. 2009). The utility function that results from the participatory process will allow the desired peri-urban agrosystem model for the future to be defined. 

for urban planning and for defining peri-urban agricultural policies, and to examine their instrumentalisation through representative groups and relevant stakeholders by checking their usefulness and social utility function. The research has been applied to the farmland area around the city of Valencia in Spain - a rich Agricultural System called Huerta de Valencia, with a variety of resources and which is currently under a political and institutional debate about how to implement a new system of protection for this area. According to the Dobris Report ((EEA) 1998) ${ }^{5}$, the Huerta de Valencia is one of the last six Mediterranean historical orchards in Europe, all of which are today in danger of extinction. The Huerta de Valencia therefore has local, regional and universal interests. An intervention policy for the conservation and preservation of this agricultural area should aim to implant a system including the performance of functions, which maximises the usefulness of the land. Cities and civil society organisations around the world (Barcelona, Milan, Paris, Madrid, London, ...) work together to enhance collaboration and to create a coordinated urban policy on sustainable food systems to deliver healthy and accessible food to all people; and peri-urban areas are considered priorities as they represent an opportunity to take actions related to this policy. Valencia has been selected as the World Capital of Sustainable Food 2017 by the United Nations Food and Agriculture Organization (FAO), and the Huerta de Valencia is a central element.

Figure 2: Huerta de Valencia area

\section{Materials and methods}

\section{Methodology}

In the context of urban planning, the participatory process contributes to the discovery of social preferences and to designing tools that maximize the usefulness of the spaces in which intervention is sought at an early stage. We propose the AHP methodology to measure social preferences and to determine the utility of peri-urban agricultural systems in order to provide information for defining management strategies for urban fringes, with specific reference to the promoting the functions, goods and services preferred by society. The AHP methodology was developed in the late 70s by Thomas Saaty and has become one of the most implemented multi-criteria methodologies. Modelling involves the establishment of a hierarchical representation of the decision problem including all relevant aspects. The basic hierarchy consists of a goal or overall objective, constituting the decision problem, and the criteria which are the elements that affect the decision. They are arranged by levels, in that we can distinguish between the main criteria, which would be the previous level to the overall objective, and for each of these criteria, there are subcriteria. Finally, the decision alternatives are considered. In the following stages, decision makers carry out pairwise comparisons of the criteria on each level of the hierarchy. The pairwise comparison allows the decision maker to express their preferences and quantify the intensity with which one criterion is preferred over another, using the measurement scale proposed by Saaty. This scale not only enables the decision

\footnotetext{
${ }^{5}$ See http://glossary.eea.europa.eu//terminology/sitesearch?term=dobris.
} 
2

3

maker to incorporate subjectivity, experience and knowledge, it is also theoretically justified, and its effectiveness has been empirically validated (Martínez 2007). As a result of the comparisons, positive reciprocal square matrices are obtained relative to various criteria and subcriteria.

Each decision maker must issue $\mathrm{Nx}(\mathrm{N}-1) / 2$ judgments about the relative importance of $\mathrm{N}$ criteria. In each matrix, the components $a_{i j}$ reflect the intensities of preference for one function over another. The preference after comparing two functions is shown on a scale of 1 to 9 . If the $i$ function is preferred, $a_{i j}$ will take a value of between 2 and 9 according to the intensity of preference, or if the $j$ function is preferred, it will take a value of between $1 / 2$ and $1 / 9$, according to the intensity.

When the group is not very large, votes can be used by consensus to decide or resolve the resulting values of the various pairwise comparisons. A large number of comparisons may hinder a consensus being reached. If agreement is not possible, each individual can solve the problem independently - and then the group priorities can be identified. Consensus may be impossible to reach because of the existence of a large number of individuals, as in processes determining social preferences.

Saaty and Vargas (2005) proposed that the members of each group individually perform pairwise comparisons and make preference judgements on alternatives; and that these should be synthesised once all the group judgements are known enabling the identification of priorities and, consequently, forming the utility or welfare function. To achieve this, the preferences shown by each individual are used, and the geometric averages of the preferences of each individual are calculated resulting in a group preference matrix that can be used to calculate group priorities.

The method of aggregating preferences or individual judgments (AIJ) to then add to the preference judgments issued by different individuals involves determining the geometric average of the judgements $a_{i j}$ of $m$ individuals within the group to obtain the matrix of comparisons or judgments of group preferences (Equation 1). The priorities of the group that form the utility function can be determined from this matrix.

$$
A=\left[a_{i j}\right]=\sqrt[m]{\prod_{k=1}^{m} a_{i j k}}
$$

The priorities of each group will be aggregated later to obtain the aggregate priorities matrix and based on this, the aggregate utility function will be determined. The priorities reflect the weights of the functions or the relative importance that stakeholder groups give to different functions. By aggregating the priorities of each group, we calculate the composition of the aggregated utility function.

The objective of the hierarchy is the maximisation of the peri-urban agricultural systems utility. Placed at the top of the hierarchy is the main objective of the decision, with the criteria and subcriteria including those aspects that determine the functionality of peri-urban agricultural systems, and they are placed on each descending level of the hierarchy. 
Multifunctionality is a conceptual framework in which farming is seen as part of a broader concept

2

that includes functions relating to environment protection and landscape, conservation of cultural heritage, improving aspects of social balance, and the provision of recreational services.

Based on the classification proposed by Abler (2001) for these goods and services and taking into account the proposals of various authors (Kallas, Rodríguez and Hurlé. 2007; Goméz-Limón, Berbel and Gutiérrez. 2007; Gómez-Limón, Picazo-Tadeo and Reig-Martínez 2008; Renting et al. 2009; Zasada 2011; Ivesa and Kendalb 2013), we made a descriptive approach for the multifunctionality of peri-urban agricultural systems (see Table 1): The goods and services in the agricultural system are differentiated between public and private goods. In terms of public goods, positive and negative externalities ${ }^{6}$ are possible, depending on whether they generate an increase or a reduction in social welfare. Finally, each of them has been classified according to some of the generic functions of peri-urban agricultural systems: Economic (E) Social (S) and Environmental (EM).

The structure is included in the definition of multifunctionality proposed by the European Commission. This scheme also coincides with the general approaches proposed by Saaty (1977) in the application of an analytical-hierarchical process in when making public policy decisions. The first function defined is the traditional economic activity that produces food and other farm commodities to be marketed. In urban fringes activities related to leisure and recreation and, to a lesser extent, to biomass production for energy from agricultural residues are considered relevant. We also include farmland as a productive asset and corporate asset. Although it is related with farmer heritage and the possibility of access to investment capital, it is not a good or service from agriculture activity. Positive externalities include: creation of important natural heritage; creation of agricultural landscapes that are much appreciated by urbanites from a visual amenity perspective for conservation and preservation purposes; conservation of biodiversity; water resources and soil protection; mitigation of the impact of greenhouse gases, which is very important for some big cities; groundwater replenishment and flood control; contribution to territorial balance through the connection of small nuclei around the city that avoid urban congestion; and the possibility of scientificcultural use. However, agricultural activity also generates negative externalities such as the consumption of water resources. Irrigated agriculture uses significantly large amounts of water, which is then unavailable to other sectors and ecosystems. In some cases, aquifers may be overexploited, which has very negative effects on the surrounding ecosystems and can even cause their disappearance. Regarding water quality, irrigated agriculture and intensive livestock farming may cause major problems by contaminating aquifers (as concentrations of leached nitrates accumulate). Thus, it is interesting that more efficient irrigation technologies and the introduction of practices to minimise and correct these problems could diffuse sources of contamination. Another problem that should be addressed is the production of healthy and safe foods without any risk to human health caused by pesticide residues.

\footnotetext{
${ }^{6}$ Refers to situations in which the producer of a particular output is not remunerated for it (positive externalities) or does not pay for its detrimental effects (negative externalities).
} 
2

3

4

5

6

7

8

9

10

11

12

13

14

15

16

17

18

19

20

21

22

23

24

25

26

27

28

29

30

31

32

33

34

35

36

37

38

39

40

41

42

43

44

45

46

47

48

49

50

51

52

53

54

55

56

57

58

59

60

1 Table 1 shows the issues to be considered for the conservation and preservation of the peri-urban

2 agricultural system. The first step is to analyse and evaluate the goods and services that the agrosystem can 3 supply. 
Table 1: Peri-urban agricultural system functions, goods and services

\begin{tabular}{|c|c|c|c|c|c|c|c|}
\hline & & Services & Explanatory functions & Goods and services & $\mathbf{E}$ & $\mathbf{S}$ & $\mathbf{M}$ \\
\hline & & 1. Land & Heritage & Land as heritage & & & \\
\hline & 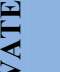 & 2. Food production & Primary production of foodstuffs & $\begin{array}{l}\text { Provides vegetable foods, seeds, plants and edible fruits, and biological } \\
\text { material }\end{array}$ & & & \\
\hline & בוּ & 3. Recreation & Generator of tourism & Provides space for eco-tourism, fishing, hunting and relaxing. & & & \\
\hline & & 4. Energy production & Biomass & Provides biomass (plant remains and energy crops) & & & \\
\hline & & $\begin{array}{l}\text { 5. Configuration of natural heritage and } \\
\text { creation of new landscapes }\end{array}$ & $\begin{array}{l}\text { Configuration of a farming system that contributes to an agrarian } \\
\text { system by creating an agricultural landscape of great value }\end{array}$ & Natural heritage and beautiful landscape & & & \\
\hline & & $\begin{array}{l}\text { 6. Protection and conservation of } \\
\text { biodiversity }\end{array}$ & Environment for animals and plants & $\begin{array}{l}\text { Enables development of biological flows. Enables preservation of plant } \\
\text { resources: populations of important species such as pollinators, native } \\
\text { species, rare or threatened species }\end{array}$ & & & \\
\hline & & 7. Protection of water resources & Water storage & & & & \\
\hline & & & Free resources by improving irrigation efficiency & Improves water supply & & & \\
\hline & & & Free irrigation resources with alternative sources & & & & \\
\hline & 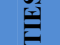 & 8. Mitigation of greenhouse effect & Sink for greenhouse gases & Regulates climate by regulating greenhouse gases & & & \\
\hline & $\bar{z}$ & & Reduction of emissions & Reduces greenhouse gas emissions using alternative energy sources & & & \\
\hline & $\underline{z}$ & & Regulation on the atmosphere's chemical composition & Contributes to improving air quality & & & \\
\hline & $\sqrt{x}$ & 9. Mitigation of disasters caused by floods, & Regulation of water flows & Improves ability to respond and adapt to natural disasters: storms, & & & \\
\hline$=$ & rit & & Retention of sediments and erosion control & & & & \\
\hline 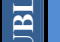 & $\sum$ & 10. Territorial and cultural scientific & Territorial equilibrium & Articulates nuclei and avoids congestion & & & \\
\hline ـ & ह & & & Creates jobs & & & \\
\hline & & & & Makes business more dynamic & & & \\
\hline & & & Cultural use & Provides a unique cultural heritage & & & \\
\hline & & & & Provides space for education & & & \\
\hline & & & Scientific use & $\begin{array}{l}\text { Provides important scientific elements: practice, vocabulary, tools, } \\
\text { infrastructure }\end{array}$ & & & \\
\hline & & 11. Land protection & Soil forming process & Favours soil formation & & & \\
\hline & & & Soil conservation & $\begin{array}{l}\text { Favours accumulation of organic matter and soil fertility by fixing } \\
\text { nutrients }\end{array}$ & & & \\
\hline & $\begin{array}{l}\overrightarrow{1} \mathbf{i} \\
\text { 되 }\end{array}$ & 12. Water resource protection & Diffuse pollution & Causes loss of quality of groundwater through pollution of aquifers & & & \\
\hline & ల్త & & Degradation of wetlands & Damages surrounding wetlands & & & \\
\hline & 焉 & 13. Production of safe healthy food & Risks to human health from pesticide residues & Interferes with supply of healthy and safe food & & & \\
\hline
\end{tabular}


The complexity arises given that there are many factors to be considered, and consequently, many levels of stakeholder actions may be involved in the decision-making process - often leading to conflicts of interest. In planning the process, we need stakeholders who contribute different levels of knowledge about the issues at hand, make assumptions that reflect their individual experiences, and produce conflicting views about desired planning outcomes. Authors support the idea that programmes developed by a variety of stakeholder groups allow parties that are relevant to a specific issue to have a say in the matter, thus increasing the legitimacy of decision making (Boström 2006). If important stakeholders are left out of the process, key issues could be ignored and consequently, the overall picture of the situation would be incomplete. This could result in finding a solution which does not deal with the real problem (Nordström, Eriksson and Öhman 2010). If the groups are well defined, the aggregated results of the different groups should be interpretable in terms of social preferences. Dietz and Stern (2008) include: elected officials, experts, those directly affected, and general public. The stakeholders who participate in the planning process should therefore belong to these four groups.

In some of the reviewed cases, stakeholder groups were relatively small, for example Moran et al. (2007) conducted a study on social preferences for a farming-environmental policy in Scotland and defined the focus groups (six groups of seven to nine participants selected from three locations). Parra-López, Calatrava-Requena and HaroJiménez (2008a) used the AHP methodology to determine an alternative to Spanish olive farming with a group of 20 experts that reviewed the best choice for present and future generations; Whitmarsh and Palmieri (2009) consulted 39 experts who represented various stakeholders (regulators, industry, environmental agencies, economic development agencies and consumer organisations); Sae-Lim et al. (2011) used AHP to determine desirable genetic characteristics for salmon with 178 breeders from five continents.

\section{Case Study: "Huerta de Valencia"}

"Huerta de Valencia" is farmland area around the city of Valencia. This is a rich Agricultural System with productive, environmental, cultural, hitoric and scenic values recognized. The farmland has been progressively reduced. Currently there are just over 17,000 hectares. The main productions are rice, vegetables and citrus fruits. All of them irrigated crops from the Turia River through a complex system of mother drains, with its arms and hijuelas. Many of these productions supply markets in Valencia City. The historical irrigation infrastructures are arabisch origin, as well as the management rules (distribution of irrigation shifts, sanctions, etc.). The "Water Court of the Plain of Valencia", is a millennial institution mundial reference on irrigation water management ("Water Court of the Plain of Valencia" was recognized in 2009 (4.COM) on the Representative List of the Intangible Cultural Heritage of Humanity by the UNESCO). It is important for its uniqueness and perfect operation constituting today, one of the most precious cultural heritage of Valencia.

The "Huerta de Valencia" agricultural landscap is very valued. It is characterized by peculiar spatial structure and composition. There are a lot of very small size plots (arround 10.000 plots) with a wide variety of crops wich creates a mosaic of very characteristic colors and textures great natural beauty. Historical irrigation infrastructures and typical farmhoses complete the rich agricultural landscape. 
1 Farming practices provide the living conditions for many plants and animals key to biodiversity conservation. In

2 addition, in Huerta de Valencia, we find sites hosting natural diversity of habitats subject to different forms of

3 protection. South of the "Huerta de Valencia" is the Albufera Natural Park. Paddy field area is located within the

4 Albufera Park. North of the "Huerta de Valencia", is the wetland "Rafalell I Vistabella" protected wetlands included

5 in the Ramsar Convention. Albufera is too, a wetland. Two areas are included in Nature 2000. The structural

6 composition and dynamics of these ecosystems are the result of interdependencies with the surrounding agricultural

7 area of Huerta de Valencia and certain agricultural practices.

We follow the scheme proposed in Table 1 to analyse and evaluate the goods and services that this agrosystem can supply distinguishing explanatory functions (subcriteria) in the generic functions (criteria). To ensure the necessary and sufficient information, we have aimed to obtain a consistent hierarchy by reducing the number of subcriteria. Explanatory functions have been grouped and the number of comparisons has been reduced in order to enable a better consistency in the pairwise comparisons results.

Figure 3: Hierarchy

First of all, the generic functions (economic, social and environmental) are compared, before comparing the explanatory functions of each of the generic functions. Therefore, the functions on a single node are only compared with each other. Stakeholders made three comparisons among the three generic functions in the criteria level of the hierarchy. Also, in the subcriteria level, they made three comparisons among the three explanatory functions of economic functions, ten comparisons among five explanatory functions of social function, and ten comparisons among five explanatory functions of environmental function. As a result of the comparisons, four positive reciprocal square matrices were obtained from each stakeholder: a $(3 \times 3)$ matrix of preferences for generic functions, a $(3 \times 3)$ matrix of preferences for explanations of the economic function, and two $(5 \times 5)$ matrices of preferences for explanatory functions of the social and environmental functions respectively. The method of aggregating preferences or individual judgments (AIJ) to add to the preference judgments issued by different individuals involves determining the geometric average of the judgements $a_{i j}$ of $m$ individuals within the group to obtain the matrix of comparisons or judgments of group preferences. From there, the priorities of the group that form the utility function can be determined.

Our study defines the stakeholder groups according to the peri-urban agricultural system and examines its functionality, including its area of influence and social interest, as well as the different aspects and areas of concern related to the functionality of this agricultural space (food production, cultural heritage conservation, ...).

In accordance with the scheme of functions, goods, and services shown in Table 1, we consider that the following stakeholder groups should be included (these groups can be identified with the participant groups defined by Dietz and Stern (2008)) (see Figure 4):

> GROUP 1, ECONOMIC SECTOR (those directly affected): Farmers and other economic activities (agricultural, leisure, tourism, restaurants, ...): representatives of private activities developed in this area, including different production models: traditional farmers, farmers practicing integrated production, organic 
production, or other sustainable production systems, representatives related to biomass and energy production, tourism activity representatives, and other economic activities in the area.

$>$ GROUP 2, SCIENTIFIC SECTOR (experts): University professors: professionals who work in the field, historians, economists, geographers, architects, heritage specialists, hydraulic engineers specialised in heritage, and specialists in farming infrastructure in general.

$>$ GROUP 3, ADMINISTRATION, government (elected officials): representatives from local, regional, or national government, with responsibilities and decision-making powers on the management of agricultural structures, regional planning and landscapes.

\section{$>$ GROUP 4, ASSOCIATIONS, FOUNDATIONS AND STUDY CENTRES (experts): environmental} organisations responsible for biodiversity, water, soil, air, and climate change, environmental groups, land management groups, and think-tanks which defend the value of historical and cultural factors in farming activities.

\section{$>$ GROUP 5, representatives of the CIVIL SOCIETY AND THE GENERAL PUBLIC of the areas under} study: (the general public represented by groups, associations, neighbourhood associations, etc. ): Nonprofit and charitable organisations interested in environmental and social benefits of the area, using public funds to promote the flow of such benefits, including neighbourhood associations).

Figure 4: Stakeholders in the Huerta de Valencia

University professors are included as professionals in order to have an expert opinion from a variety of fields, thus enabling us to understand the economic and productive reality of the Huerta de Valencia. The participation of this group is very important for the later stage which defines potential and operating alternatives, and future scenarios. Therefore, it is important that professors from the departments of agricultural economics and plant production in Valencian universities and who have conducted research in this area participate and express their preferences.

\section{$\underline{\text { Data collection }}$}

Preferences are identified through a survey. Collecting and merging the different stakeholders' preferences with the group preferences and reaching the final group decision(s) are challenging tasks that can be facilitated by applying contemporary tools and techniques from mathematical models to computer applications (Lakicevica, Srdjevica, and Srdjevi 2014). New information technologies offer the public an opportunity to participate. Digital questionnaires and the use of social networks and websites for distribution facilitate data collection for further processing. These tools make it easier for the public to participate. The use of various digital mechanisms for public participation encourages coordination among stakeholders and facilitates communication and exchanges for decision making (Mesa, Martín-Ortega, and Berbel 2008).

We designed a specific questionnaire in digital format to collect the opinions of the experts (Figure 5). The questionnaire must be easy to use and understand in order to facilitate reflection and decision making. Its content, structure and design are very important in the sense that the respondent should be able to respond individually and express their personal experience. As well as including the questions, the questionnaire should describe: decision 
making in agrosystems; AHP hierarchy; the Saaty scale; and how to make pairwise comparisons. We invited stakeholders to provide expert assessments through an Internet survey. In Figure 4 we include some images from the digital questionnaire referring to the questions about preferences for economic and social functions.

\section{Figure 5: Economic and social questions in the questionnaire}

The questionnaire was sent by email to the representatives of the various stakeholder groups, informing them of the development of the study and inviting them to participate in it. As mentioned above, the arrangement of the document submitted allowed them to answer on the open digital document itself, and easily send a file with the data. The questionnaire was posted on the Polytechnic University of Valencia website where it could be accessed and answered. The document provided information on generic and explanatory functions, as well as on the goods and services provided by the agricultural system of the Huerta de Valencia. Each explanatory function is described in a clear and brief text, accompanied by representative photographs to help understand each case. All materials were available for stakeholders, so they could read them at their own pace. The questionnaire begins with several socioeconomic questions. All combinations of pairs of generic functions and of explanatory functions were suggested to the interviewees for comparison. There were 26 pairwise comparisons. The generic functions could be identified by specific colours, which were the same as those that appeared in the hierarchy box. As shown in the attached format questionnaire, Saaty's assessment scale was charted in each pairwise comparison, for the purpose of clarifying the functions that were compared in each case, and help stakeholders decide which function is preferred and the intensity of such preference. Thus, the aim was to help the stakeholder to express their opinion or preference, in an intuitive and simple way, to allow them to quickly identify the functions to be compared, and to help define their preference for a particular function and its intensity. From the central position of indifference regarding two functions, the scale shifts left or right in intensity - left to define preference for the first function (left) over the second function (right), or right to define preference for the second function (right) over the first (left). The scale value sets the intensity of these preferences.

We calculated the consistency index of the four matrices from each group and noted that almost all had levels of inconsistency of around 0.01 or lower (and therefore below the maximum level set by Saaty 0.1 ). The aggregated preference matrices could therefore be considered valid, and from there we calculated the priorities of each group.

Individuals or members of each group were established based on the organisations that defined each group, with the groups not weighted for the calculation of the aggregated utility function. The distribution of individuals among the groups was initially set at $20 \%$ for group 1 (G1), $25 \%$ for group 2 (G2), $32 \%$ for group 3 (G3) (which includes all the municipalities in the metropolitan Valencia area and the regional administration responsible for land, air quality, water quality, and landscape protection), $10 \%$ for group 4 (G4), and $13 \%$ for group 5 (G5).

Table 2 shows the results of the interviews with the stakeholders, the number of participants who received the questionnaire, the number of participants who responded, the percentage of participation and the weight of each group. 
Table 2: Stakeholder summary

\begin{tabular}{|c|c|c|c|c|c|}
\hline & & $\ddot{\varpi}$ & 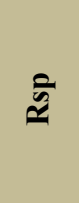 & ○゚ & $\frac{\sum}{3}$ \\
\hline \multicolumn{2}{|c|}{ G1: ECONOMIC SECTOR (those directly affected) } & 129 & 23 & $17,83 \%$ & $16,43 \%$ \\
\hline Urban farming & Hort de Perot, Hort de Carme, Huertos del Turia, ... & 14 & 1 & & \\
\hline Municipal farming & Godella, Massamagrell, Benimaclet, Aldaia, Picanya, ... & 6 & 0 & & \\
\hline Solidarities farming & Cárirtas. Avenida de la Plata, CEM Julià Paterna, ... & 5 & 0 & & \\
\hline Farmers & Martí, Vicent Marco, Terra i Salut, ... & 12 & 11 & & \\
\hline $\begin{array}{l}\text { Farmers of Organic } \\
\text { Production }\end{array}$ & $\begin{array}{lllll}\text { El Coscollar, Horts } & \text { Eco-urbans, Sembra en } & \text { Saó, } \\
\text { Ecomediterránea }\end{array}$ & 5 & 5 & & \\
\hline $\begin{array}{l}\text { Other activities in the } \\
\text { area }\end{array}$ & $\begin{array}{l}\text { Afrasa, Horta Viva, Terra i Xufa, Naturalgar, Horta directa, } \\
\text { Terra i salut, ... }\end{array}$ & 57 & 4 & & \\
\hline \multirow[t]{4}{*}{ Farmers' associations } & Asociación Valenciana de Agricultores, Fumava & 12 & 0 & & \\
\hline & $\begin{array}{l}\text { La Unió, Fundació Institut Valencià d'Investigació i Formació } \\
\text { Agroambiental }\end{array}$ & 15 & 2 & & \\
\hline & Asociació de Llauradors de Puçol & 1 & 0 & & \\
\hline & $\begin{array}{l}\text { ConsejoRegulador de la Denominación de Origen Chufa de } \\
\text { Valencia }\end{array}$ & 2 & 0 & & \\
\hline \multicolumn{2}{|c|}{ G2: SCIENTIFIC SECTOR (experts) } & 88 & 32 & $36,36 \%$ & $22,86 \%$ \\
\hline $\begin{array}{l}\text { Universitat politècnica } \\
\text { deValència }\end{array}$ & $\begin{array}{l}\text { University professors in Departments: Economy and Social } \\
\text { Sciences, Biotechnology, Agricultural Engineering, Plant } \\
\text { Production }\end{array}$ & 88 & 32 & & \\
\hline \multicolumn{2}{|c|}{ G3: ADMINISTRATION (elected officials) } & 205 & 39 & $19,02 \%$ & $27,86 \%$ \\
\hline \begin{tabular}{l|l} 
Regional \\
Administration
\end{tabular} & Department of Planning and Landscape & 41 & 12 & & \\
\hline Local Administration & City Councils Metropolitan Area of Valencia & 164 & 27 & & \\
\hline \multicolumn{2}{|c|}{ G4: ASSOCIATIONS, FOUNDATIONS AND STUDY CENTRES (experts) } & 105 & 22 & $20.95 \%$ & $15,71 \%$ \\
\hline Biodiversity & Institut Cavanilles de Biodiversitat, Llavors d'Ací,... & 37 & 1 & & \\
\hline Sociology & $\begin{array}{l}\text { Instituto Interuniversitario de Desarrollo Local, Fundación } \\
\text { Ceps... }\end{array}$ & 19 & 5 & & \\
\hline $\begin{array}{l}\text { Economy and Rural } \\
\text { development }\end{array}$ & $\begin{array}{l}\text { International Centre of Research and Information on the } \\
\text { Public, Social and Cooperative Economy, Applied Economics } \\
\text { Department (Universitat de València) }\end{array}$ & 8 & 6 & & \\
\hline Water & Seiasa, CEV-UPV & 9 & 0 & & \\
\hline Geography & Col.lectiuy de geografs, Institut d'Estudis Valencians, & 12 & 4 & & \\
\hline Planning & $\begin{array}{l}\text { Institut del Territori, Departament of Urbanism (UPV), } \\
\text { Institute of Social Economy and Cooperation }\end{array}$ & 5 & 2 & & \\
\hline Heritage & $\begin{array}{l}\text { Fundació Assut, Centre d'Estudios de L'Horta Nord, PAISAR, } \\
\text { Research Group on Lansdcape and Architecture }\end{array}$ & 15 & 4 & & \\
\hline \multicolumn{2}{|c|}{ G5: Representatives of the CIVIL SOCIETY AND THE GENERAL PUBLIC } & 135 & 24 & $17,78 \%$ & $17,14 \%$ \\
\hline $\begin{array}{l}\text { Neighbourhood } \\
\text { associations }\end{array}$ & $\begin{array}{l}\text { Federación de AAVV de Valencia, AV Barrrio San José, Gent } \\
\text { del Carme, Patraix, }\end{array}$ & 55 & 5 & & \\
\hline $\begin{array}{l}\text { Environmentalists } \\
\text { groups }\end{array}$ & Acció Ecologista Agró, La Colla, Ecologistas en acción,... & 5 & 1 & & \\
\hline $\begin{array}{l}\text { Associations and } \\
\text { Groups }\end{array}$ & Per l'Horta, Sembra en Saó, Repensem 1'Horta, ... & 73 & 16 & & \\
\hline \multicolumn{2}{|c|}{ Professional Associations: Colegio Oficial de Ingenieros Agrónomos } & 2 & 2 & & \\
\hline
\end{tabular}


A total of 660 questionnaires were sent to the stakeholders. There were a total of 140 responses to the mailout survey. G1 (representatives of farmers and economic activities) together with G5 (representatives of the general public) showed the least interest in participation, with only $18 \%$ of the representatives invited participating. The percentage of participants from the administration was similar (19\%). The G4 (associations, foundations and study centres) participation was slightly higher $(21 \%)$, and the group that most participated were the university professors $(36 \%)$.

In the questionnaire, farmers stated whether they practiced integrated or organic production, or other sustainable production systems. However, in the end, we considered both groups regardless of their responses to this question, as only some of them (5 participants) answered this question. If we consider the preferences of the farmers who stated that they practice organic farming, results show differences in preferences. But there were not enough answers to obtain reliable conclusions.

\section{Results}

Table 3 shows the priorities given by each group to each explanatory function. It is possible to use the priorities of each group and aggregate them to obtain the priorities of the stakeholders as a whole (aggregation of stakeholders) for each explanatory function.

Table 4 shows the utility function for each stakeholder group. We can observe the results from the weights of the generic functions and of the explanatory functions. This table also shows the importance of each function in the utility function, and the aggregated utility function for all groups.

Concerning the results in Table 3, if we examine the matrices resulting from the aggregation of group preferences for the explanatory functions within the economic functions, all groups gave a weight of around $50 \%$ to the function of providing farm income, although this figure increased to $66 \%$ for G1. Social functions were also important for farmers since they provide employment opportunities, as well as the production of healthy and safe food. G1 (farmers) gave little importance to landscape protection compared to other groups. G4 (associations, foundations ...) gave the greatest importance to this function. G4 also highlighted the role of contributing to the creation and preservation of scientific and cultural heritage. Both of these roles are key elements in the development of tourism activities, and in this sense, G4 highlighted the role of tourism in providing an alternative income more than any other group $(38.4 \%)$.

All groups gave an equal weight to the role of conservation and protection of biodiversity. They also gave some importance to the role of absorption of $\mathrm{CO} 2$ (around $20 \%$ ), but G1 (farmers) raised this to $27.64 \%$, while G4 (associations, foundations ...) did not allocate more than $12.5 \%$.

The results concerning the preferences of the farmer group could indicate the existence of an activist group of farmers who are especially interested in new values related to the production of safe and healthy food and the development of beneficial processes such as $\mathrm{CO} 2$ fixation. This group may also be open to tourism as an additional but supplementary income ( $23.43 \%$ of weight given to the role of tourism for providing income, compared to almost $66.14 \%$ for farming). 
Those groups that gave less importance to the economic role of the farmland also gave less importance to the 2 role of providing income for farmers. Nevertheless, the provision of income for farmers was seen as the most 3 important role for all groups (greater than $45 \%$ ). Those groups who gave greater importance to providing income 4 from leisure and recreation activities also gave greater importance to the value of an agricultural landscape, the 5 protection of biodiversity, and cultural heritage (G4). The importance given to the landscape by groups such as 6 university professors (G2), administrators (G3), associations, foundations, etc. (G4) is also noteworthy (exceeding by 7 more than 10 points in comparison to the importance given by groups such as farmers (G1) and even the general 8 public of this area (G5). The actions taken by the administration to protect the landscape may explain the importance 9 given to the landscape (24.94\%).

The priorities of each group were aggregated to obtain the priorities of the stakeholders as a whole, in addition to the aggregated utility function. Results can be seen in Table 4. Similarities among groups were observed in the utility functions obtained. Thus, administrators (G3) and the general public of this area (G5) presented weights for the main functions and explanatory functions with very little variation, not exceeding two percentage points. University professors (G2), on the other hand, had a utility function that was similar to the aggregated utility function - with weightings very similar to the generic functions, and a distribution of weights of the explanatory functions that were very similar to those of the aggregated function. Social function is pretty underrepresented throughout for most groups (G1, G2, G3, G5). For G4 it is more important, particulary because create goods of cultural and scientific interest, produces healthy, safe foods and an attractive agrarian landscape.

Within the group of farming representatives, if we differentiate the farmers who apply integrated production techniques, organic, or other sustainable production systems, then the weight they attached to the economic function was reduced to $30.93 \%$, with the social function at $31.33 \%$ and environmental function at $37.73 \%$. The weight they attached to producing healthy and safe food reached the highest values of all groups. However, the results are not included in any table because they are inconclusive, and more participants would be necessary, i.e. we do not have enough information to provide significant conclusions. This is a question, nonetheless, which could be addressed in future research projects. 
Table 3: Weights of the subcriteria according to stakeholders (AIJ)

\begin{tabular}{|c|c|c|c|c|c|c|c|c|c|c|c|c|c|}
\hline $\begin{array}{c}\text { GENERIC FUNCTIONS } \\
\text { (CRITERIA) }\end{array}$ & \multicolumn{3}{|c|}{$\begin{array}{l}\text { ECONOMIC } \\
\text { FUNCTIONS }\end{array}$} & \multicolumn{5}{|c|}{ SOCIAL FUNCTIONS } & \multicolumn{5}{|c|}{ ENVIRONMENTAL FUNCTIONS } \\
\hline $\begin{array}{c}\text { EXPLANATORY FUNCTIONS } \\
\text { (SUBCRITERIA) }\end{array}$ & wEI & wT & wEng & wCity & wJob & $\mathrm{wC} \& \mathrm{~S}$ & wSF & wAL & wBIOdv & wSCO2 & $\mathrm{wQH} 2 \mathrm{O}$ & wPrtSoil & wRdist \\
\hline Aggregation of stakeholders & $52.68 \%$ & $28.94 \%$ & $18.38 \%$ & $10.31 \%$ & $21.09 \%$ & $16.48 \%$ & $29.69 \%$ & $22.44 \%$ & $25.63 \%$ & $20.43 \%$ & $12.94 \%$ & $22.78 \%$ & $18.22 \%$ \\
\hline G1: Farmers and others & $66.14 \%$ & $23.43 \%$ & $10.43 \%$ & $9.96 \%$ & $31.25 \%$ & $11.04 \%$ & $35.24 \%$ & $12.52 \%$ & $25.90 \%$ & $27.64 \%$ & $13.83 \%$ & $15.98 \%$ & $16.65 \%$ \\
\hline G2: University professors & $50.57 \%$ & $29.37 \%$ & $20.06 \%$ & $10.09 \%$ & $22.93 \%$ & $14.14 \%$ & $28.02 \%$ & $24.81 \%$ & $21.95 \%$ & $21.91 \%$ & $14.22 \%$ & $25.00 \%$ & $16.91 \%$ \\
\hline G3: Administration & $48.79 \%$ & $30.84 \%$ & $20.36 \%$ & $8.88 \%$ & $24.54 \%$ & $15.49 \%$ & $26.15 \%$ & $24.94 \%$ & $25.19 \%$ & $19.20 \%$ & $12.41 \%$ & $23.85 \%$ & $19.35 \%$ \\
\hline G4: Associations, foundations ... & $45.50 \%$ & $38.40 \%$ & $16.10 \%$ & $9.66 \%$ & $9.57 \%$ & $27.88 \%$ & $21.28 \%$ & $31.62 \%$ & $29.43 \%$ & $12.50 \%$ & $12.82 \%$ & $28.14 \%$ & $17.11 \%$ \\
\hline G5: General public of the area & $49.60 \%$ & $22.60 \%$ & $27.79 \%$ & $11.13 \%$ & $20.40 \%$ & $14.83 \%$ & $34.53 \%$ & $19.11 \%$ & $24.56 \%$ & $22.95 \%$ & $10.88 \%$ & $21.41 \%$ & $20.19 \%$ \\
\hline
\end{tabular}

E: economic. S: social. EM: environmental. EI: economic income from sales of farm products. T: rural tourism business. Eng: biomass production to generate energy to sell. City: Favours the link and helps avoid city congestion. Job: Offers job opportunities. C\&S: Create goods of cultural and scientific interest. SF: Produces healthy, safe foods. AL: attractive agrarian landscape; BIOdv: Promotes biodiversity. $\mathrm{SCO}_{2}$ : Carbon sequestration. $\mathrm{QH}_{2} \mathrm{O}$ : quality water. PrtSoil: Protects soil. Rdist: reduces effects of disasters caused, etc. 
1

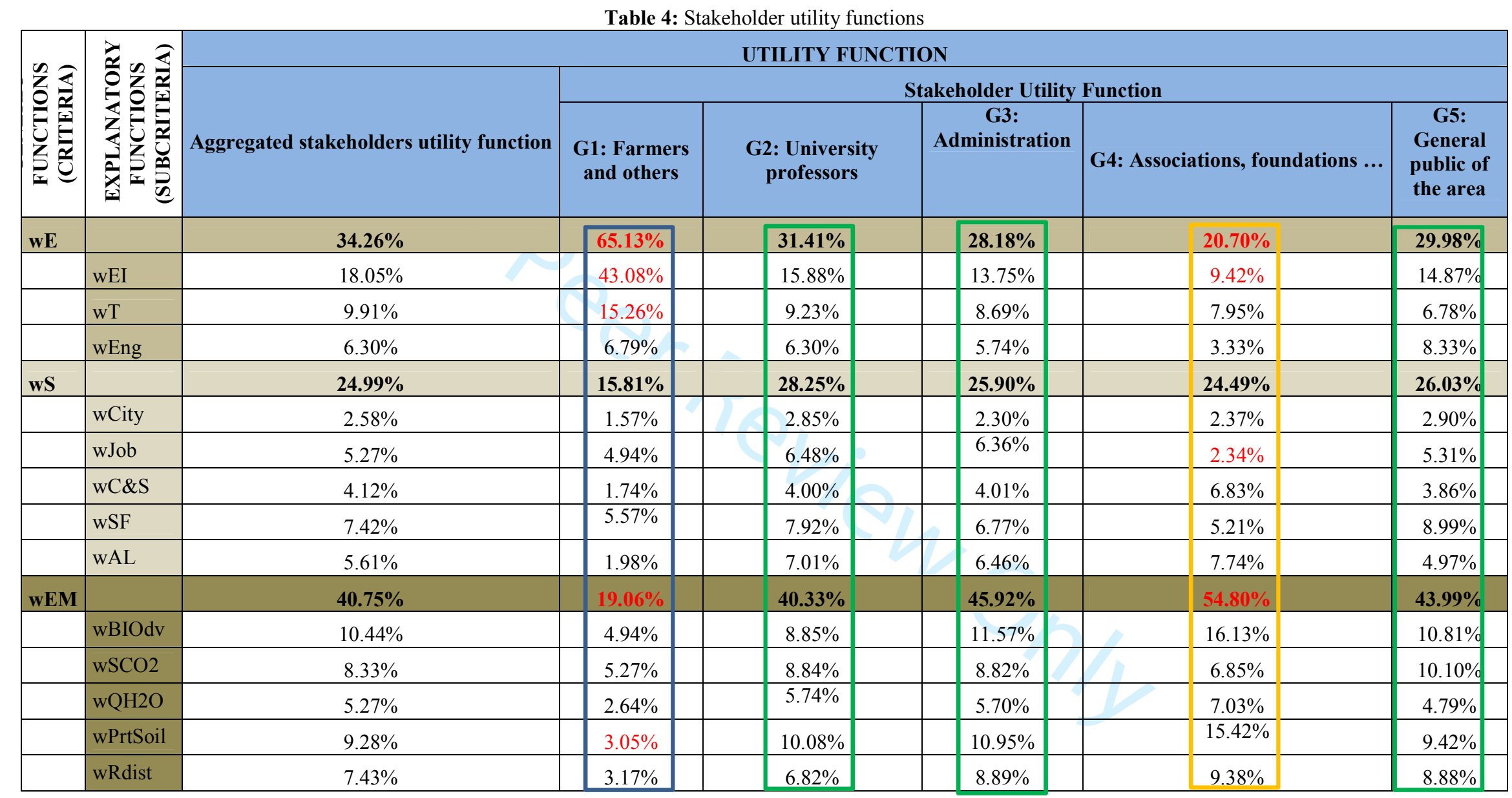




\section{Discussion}

The aim of this article is to improve methodologies for public participation by examining their instrumentalisation through representative groups and relevant stakeholders as well as their usefulness and social utility function. The study calculates the weighting of functions which explain the maximum utility of the Huerta de Valencia assuming that:

- the pairwise comparisons in the hierarchy from each stakeholder are the preferences we use to calculate priorities, and therefore the values of the weightings are better justified,

- any arbitrarily large number of experts can express their preferences,

- the expert judgment consistency should be evaluated and maintained at a possible low level.

From the results of preferences, we can differentiate alternative agricultural systems for the area. We base our work on a proposal for the study area from García Álvarez-Coque and López-García (2011) who define four plausible future land use scenarios, based on management systems. The models we can define which fit the preferences of the different groups (Table 4) are:

- Intensive farming systems: for G1. Requires land, water and labour resources, all of which is very challenging or problematic in the peri-urban space

- Sustainable farming systems: for G2, G3 and G5. Intervention policies focus on agricultural activities aimed at new products to meet rising demand and integrated in food policies. Sustainable agriculture that provides healthy and safe foods, and increases the income received by other complementary activities.

- Territorial management systems: for G4. Predominance of alternative land uses: leisure orchards, education, biodiversity, landscape protection, remaining the agricultural activity subject to the territorial action determinations.

Sustainable farming systems would represent the aggregate function. Therefore, it could be interpreted as a socially desirable model.

We identify the vertical and horizontal interplay among actors (stakeholders) at different levels and with different interests, in addition to analysing actors at regional and local levels, and actors from other affected sectors. Critics (Newig and Fritsch 2009) have questioned the contribution of participation to simplify the implementation of environmental decisions. They found that participatory processes helped to implement environmental decisions, in situations with low levels of conflicts that were not in the public spotlight, with little asymmetry in power and the presence of win-win potential, as well as an appropriate representation of social interests and a fair participatory process. The number of participants in the individual groups was unbalanced. A questionnaire was sent to a list of members in each stakeholder group, but only 140 responded (Sae-Lim et al. 2011; Whitmarsh and Palmieri 2009). The possibility of balancing each group (the number of members) could be explored in future studies. The simplest system would be to set an equal number of experts per group (Parra-López et al. 2008b), or depending on the nature of the criteria (Dietz and Stern 2008; Newig and Fritsch 2009). Some authors have suggested that in order to 
2

prioritise, it is necessary not only to know the interest groups, but also to consider their weights or influence in decision making, to weigh the priorities in the aggregate utility function of all groups (as a requirement), so that it can be interpreted as a social function (Hauck, Schmidt, and Werne 2016).

When stakeholders are adequately defined and well represented, their aggregated preferences should represent social preferences. However, the results of this study should not be used in this sense, given the limited participation (only $25 \%$ of those invited to participate did so). Nevertheless, it would be appropriate to analyse the dispersion of individual preferences within groups considered to be homogeneous, to be able to assess whether the aggregation methodology (AIJ) is the most suitable approach or whether groups are heterogeneous and individual priorities should be added to calculate the group priorities. If so, then the five distinct groups should be divided into smaller groups which are more homogeneous in their preferences. A division of the groups that could be very useful in future work is shown in the Table below:

\section{Table 5: Disaggregation of stakeholders}

\begin{tabular}{|l|}
\hline Farmers \\
\hline Farmers (Integrated agricultural production) \\
\hline University professors \\
\hline Representative of bodies managing water resources \\
\hline $\begin{array}{l}\text { Employers or their representatives with activities in the farmland: } \\
\text { touristic, industrial and nurseries }\end{array}$ \\
\hline Representatives of metropolitan neighbourhood associations \\
\hline Local administrators from the metropolitan area \\
\hline Regional land use administrators \\
\hline Environmental groups \\
\hline Members of associations, foundations and study centres \\
\hline $\begin{array}{l}\text { Representatives of organisations that bring together private companies } \\
\text { that allocate resources to land stewardship }\end{array}$ \\
\hline $\begin{array}{l}\text { Non-profit organisations interested in environmental and social benefits } \\
\text { of the area using public funds to encourage such benefits }\end{array}$ \\
\hline
\end{tabular}

The use of web tool support systems for decision making is becoming more common in planning. In terms of problem solving and decision making, these tools are interesting for planning in any field including agricultural and environmental planning. The use of various digital mechanisms for public participation encourages coordination among stakeholders and facilitates communication and exchanges for decision making (Mesa, Martín-Ortega, and Berbel 2008). In our study, however, the participation data in Table 2 does not provide good results. It was only in the group of university experts that participation was high. In fact, several mailings were required to obtain an adequate number of replies. The format used for the questionnaire (PDF) was easy to access, depending on the stakeholder's email settings. It had to be downloaded to the computer desktop to be answered and then sent back. This could have made the access process more difficult, although sending it was easy because of its simple format. Its format also allowed for a more appropriate presentation of each theme, which included graphs, images and texts in attractive and reader-friendly formats that facilitated the decision process. Its settings enabled the data collection to be 
presented in a XML file, making the data very easy to process and subsequently obtaining the aggregated values through Excel. Nowadays, web questionnaires can be drawn up using Google or similar applications with good operability. However, their settings are too simple and limit the possibilities of using new and interesting techniques for studies on preferences and decision making, such as multi-criteria techniques, where it is necessary to include special scales, additional information on decision alternatives, hierarchies, etc. Thus, the design of questionnaires should be developed with the aim of designing ad-hoc questionnaires that facilitate respondents' access, provide them with the necessary and sufficient information, and foster an adequate participation in decision making.

\section{Conclusions}

To be able to maintain peri-urban agricultural systems, urban planning in developed countries should aim to conserve these multifunctional peri-urban agricultural systems, whereas agricultural policies should consider how to restructure the system of traditional agricultural production of market goods, replacing it with a new system designed to meet the demands of modern urban society.

The European Union, for instance, released several directives which demand public participation in decision-making processes concerning environmental and land use issues. Involving citizens in urban or territorial planning to design peri-urban agricultural areas requires a consultation process when the planning process begins, so that the authorities know the preferences and can design urban growth strategies and take decisions about the conservation of farmland. However, at successive stages in the planning process, once it is more detailed, then participants should be involved in those stages. When the urban planning goes forward, stakeholder participation increases the influence of planning decisions.

One of the main problems is finding a way to incorporate public opinion in the final decisions. This research offers one possible alternative to deal with this concern. Our paper proposes to use methods of social choice theory which emphasizes the importance of public participation in urban planning decision making, and proposes one possible participation system. Huerta de Valencia is an agricultural system with great wealth and a variety of resources, and which is the subject of an open political-institutional debate to design a protection scheme. Our research aims to show the importance of participatory decision making through the participation of local communities represented by stakeholders. The results should be integrated into the political and institutional decision-making process of intervention policies currently developed for this agricultural area in order to design the protection scheme. It is expected that it will be widely accepted, and thus facilitate policy implementation.

As a result, AHP is an interesting methodology for determining social preferences. The data on preferences was collected through a survey sent in an easy-to-use and participative digital format to representatives of various groups of interest. We had hoped that using new technologies would encourage greater participation.

Each group of interest was considered, by its very nature and definition, as homogeneous in relation to the preferences of its individual members. Therefore, we aggregated the preferences of the 
members using the geometric mean method to obtain group preferences, and from there we obtained the group priorities using the Eigen vector method. Although some members of the group were inconsistent in their choices, after aggregating all members, the group results showed consistency.

Regarding the group preferences, we calculated the priorities of each group and the aggregated utility function. As expected, we noticed significant differences among the utility functions of different groups, but also some remarkable similarities among some of the groups. Important differences can be seen in the weights given by the different groups to the generic functions or specific functions. As a result, the aggregated utility function differs from the utility function of each group. The main differences are in G1's (farmers and other economic activities) utility function, because of the high weight given to the economic function, and the low weight to the environmental function. On the contrary, in G4's (associations, foundations, ...) utility function, a high weight is given to the environmental function and a low weight to the economic function. If we consider the specific functions, the main differences are also between those two groups: G1 (farmers and other economic activity) and G4 (associations, foundations ...). We can observe that some groups have a similar utility function to their aggregated utility function: G2 (university professors), G3 (administration) and G5 (general public of the area).

This research can be considered as a prior consultation to collect data in the first stage of the territorial planning process for the city of Valencia and its metropolitan area, the objective being to design conservation strategies for this agricultural system. Results in Table 4 show there is a high likelihood of regional conflict when addressing the design of territorial planning around the Huerta de Valencia. Those groups with greater capacity to influence decisions, such as government officials, through political manipulation, and university professors, through opinion and editorial articles, can play a determinant role in the final planning. The design process could include the proposed method to seek a formula for consensus which results in policies that are consistent with all social preferences.

The present study can be a starting point for further research. However, in future work it would be advisable to study the dispersion of preferences among the different members of groups so as to examine the homogeneity/heterogeneity of the members before deciding on the AIJ/AIP aggregation methodology, or disaggregating the groups into more homogeneous groupings.

\section{References}

Abler, D. 2001. A synthesis of country reports on jointness between commodity and non-commodity outputs in OECD agriculture. Workshop on Multifunctionality, OCDE, Paris.

Ahtiainen, H., E. Pouta, E. Liski, S. Myyrä, and A. Assmuth. 2015. Importance of Economic, Social, and Environmental Objectives of Agriculture for Stakeholders-A Meta-Analysis. Agroecology and Sustainable Food Systems 39 (9): 1047-1068.

Ananda, J., and G. Herath. 2008. Multi-attribute preference modelling and regional land-use. Ecological Economics 65: 325-335. 
1 Aull-Hyde, R., S. Erdogan, and J.M. Duke. 2006. An experiment on the consistency of aggregated comparison matrices in AHP. European Journal of Operational Research 171: 290-295.

Boström, M. 2006. Regulatory credibility and authority through inclusiveness: Standardization organizations in cases of eco-labelling. Organization 13 (3): 345-367.

Cai , C. M., and J. C. Shang . 2009. Comprehensive Evaluation on Urban Sustainable Development of Harbin City in Northeast China. Chinese Geographical Science 19: 144-150.

Clark, J., J. Burgess, and C. M. Harrison. 2000. 'I struggled with this money business': respondents perspectives on contingent valuation. Ecological Economics 33: 131-145.

Dehnhardt, A., and J. Meyerhoff. 2002. Nachhaltige Entwicklung der Stromlandschaft Elbe. Kiel: Wissenschaftsverlag Vauk Kiel KG..

Dietz, T., and P. C. Stern. 2008. Public participation in environmental assessment and decision making. Washington, D. C.: National Research Council, National Academies Press.

Dinc, M., K. E. Haynes, and M. Tarimcilar. 2003. Integrating models for regional development decisions: A policy perspective. Annals of Regional Science 37: 31-53.

Dong, Y., Y. Xu, H. Li, and M. Dai. 2008. A comparative study of the numerical scales and the prioritization methods in AHP. European Journal of Operational Research 186 (1): 229-242.

Duke, J. M., and R. Aull-Hyde. 2002. Identifying public preferences for land preservation using the analytic hierarchy process. Ecological Economics 42: 131-145.

Elhadary, Y. A. E., N. Samat, and F. Obeng-Odoom. 2013. Development at the Peri-Urban Area and Its Impact on Agricultural Activities: An Example from the Seberang Perai Region, Penang State, Malaysia. Agroecology and Sustainable Food Systems 37 (7): 834-856.

European Commission, DG Agriculture. Safeguarding the multifunctional role of agriculture: which instruments?. Report from the Commission to the Special Committee on Agriculture in Berlin. Info-Paper. Brussels, 1998.

European Environmental Agency. 1998. Dobris Report

Fernández, M., K. Goodall, M. Olson, and V. Méndez. 2013. Agroecology and alternative agri-food movements in the United States: Toward a sustainable agri-food system. Agroecology and sustainable food systems 37 (1): 115-126.

Filippini, R., E. Marraccini, M. Houdart, E. Bonari, and S Lardon. 2016. Food production for the city: hybridization of farmers' strategies between alternative and conventional food chains. Agroecology and Sustainable Food Systems 40 (10): 1058-1084. 
García Álvarez-Coque, J.M., and T. López-García. 2011«Viabilidad del Espacio Agrario Urbano de la Huerta de Valencia. In III Congrés d'Estudis de 1'Horta Nord, congress proceedings, 653-670. Polythecnic University of Valencia, Valencia (Spain).

Gómez-Limón, J. A., A. J. Picazo-Tadeo, and E. Reig-Martínez. 2008. Agricultura, desarrollo rural y sostenibilidad medioambiental. Ciriec-España 61: 103-126.

Goméz-Limón, J. A., J. Berbel, and C. Gutiérrez. 2007. Multifuncionalidad del regadío: una aproximación empírica. In La multifuncionalidad de la agricultura española. Conceptos, aspectos horizontales, cuantificación y casos prácticos, 207-224. Madrid: Eumedia y Ministerio de Agricultura, Pesca y Alimentación..

Gómez-Navarro, T., M. García-Melon, S. Acuna-Dutra , and D. Diaz-Martín. 2009. An environmental pressure index proposal for urban development planning based on the analytic network process. Environmental Impact 29: 319-329.

Haase, D., and H. Nuissl. 2007. Does urban sprawl drive changes in the water balance and policy? The case of Leipzig (Germany) 1870-2003. Landscape and Urban 80: 1-13.

Hauck, J., J. Schmidt, and A. Werne. 2016. Using social network analysis to identify key stakeholders in agricultural biodiversity governance and related land-use decisions at regional and local level. Ecology and Society 21 (2): art. 49.

Hutchinson, J. J., C. A. Campbell, and R. L. Desjardins. 2007. Some perspectives on carbon sequestration in agriculture. Agricultural and Forest Meteorology 142: 288-302.

Ivesa, C. I., and D. Kendalb. 2013. Values and attitudes of the urban public towards peri-urban agricultural land. Land Use Policy 34: 80-90.

Jacobs, M. 1997. Environmental valuation, deliberative democracy and public decision making institutions. In Valuing Nature? Economics, ethics and environment, ed. J. Foster, ch. 13, 211-231. London and New York: Routledge.

Kallas, Z., J. A. Rodríguez, and J. B. Hurlé. 2007. Oferta y demanda de bienes y servicios públicos en la agricultura española. In La multifuncionalidad de la agricultura en España: concepto, aspectos horizontales, cuantificación y casos prácticos, 131-153. Madrid: Ministerio de Agricultura, Alimentación y Medio Ambiente.

Kangas, J., and P. Leskinen. 2005. Modelling ecological expertise for forest planning calculationsrationale, examples, and pitfalls. Journal of Environmental Management 76: 125-133.

Koczkodaj, W. W., K. Kułakowski, and A. Ligęza. 2014. On the quality evaluation of scientific entities in Poland supported by consistency-driven pairwise comparisons method. Scientometrics 99(3): 911926. 
Kok, K., and T. Veldkamp. 2011. Scale and governance: conceptual considerations and practical implications. Ecology and Society 16 (2): art. 23.

Lakicevica, M., Z. Srdjevica, and B. Srdjevi. 2014. Decision making in urban forestry by using approval voting and multicriteria approval method (case study: Zvezdarska forest, Belgrade, Serbia). Urban Forestry \& Urban Greening 13 (1): 114-120.

Lamptey, B. L., E. J. Barron, and C. Pollard. 2005. Impacts of agriculture and urbanization on the climate of the Northeastern United States. Global and Planetary Change 49: 203-221.

Madureira, L., T. Rambonilaza, and I. Karpinski. 2007. Review of methods and evidence for economic valuation of agricultural non-commodity outputs and suggestions to facilitate its application to broader decisional contexts. Agriculture, Ecosystems and Environment 120: 5-20.

Maier, C., T. Lindner, and G. Winkel. 2014. Stakeholders' perceptions of participation in forest policy: A case study from Baden-Württemberg. Land Use Policy 39 (July): 166-176.

Marqués-Pérez , I., and B. Segura. 2016. Identifying Functionality of Peri-Urban Agricultural Systems: A Case Study. In Urban Agriculture, ed. M. Samer, chap. 5, 138. InTech.

Martínez, E. 2007. Aplicación del proceso jerárquico de análisis en la selección de la lozalización de una PYME. Anuario jurídico y económico escurialense 40: 523-542.

Mesa, P., J. Martín-Ortega, and J. Berbel. 2008. Análisis multicriterio de preferencias sociales en gestión hídrica bajo la Directiva Marco del Agua. Economía Agraria y Recursos Naturales 8 (2): 105-126.

Mincyte, D., and K. Dobernig. 2016. Urban farming in the North American metropolis: Rethinking work and distance in alternative food networks. Environment and Planning A 48 (9): 1767-1786.

Moran, D., A. McVittie, D. J. Allcroft, and D .A. Elston. 2007. Quantifying public preferences for agrienvironmental policy in Scotland: A comparison of methods. Ecological Economics 63: 42-53.

Munda, G. 1996. Cost-benefit analysis in integrated environmental. Ecological Economics 19 (2): 157-168.

Newig, J, and O Fritsch. 2009. Environmental governance: participatory, multi-level-and effective?. Environmental policy and governance 19 (3): 197-214.

Nordström, E. M., L. O. Eriksson, and K. Öhman. 2010. Integrating multiple criteria decision analysis in participatory forest planning: Experience from a case study in northern Sweden. Forest Policy and Economics 12 (8): 562-574.

Opitz, I., R. Berges, A. Piorr, and T. Krikser. 2016. Contributing to food security in urban areas: differences between urban agriculture and peri-urban agriculture in the Global North. Agriculture and Human Values 33: 341-358. 
1 Parra-López, C., J. Calatrava-Requena, and T. de Haro-Giménez. 2008a. A systemic comparative assessment of the multifuntional performance of alternative olive system in Spain within an AHPextended framework. Ecological Economics 64 (4): 820-834.

Parra-López, C., J. C. J. Groot, C. Carmona-Torresa, and W. A. H. Rossing. 2008b. Integrating public demands into model-based design for multifunctional agriculture: An application to intensive Dutch dairy landscapes. Ecological Economics 67 (4): 538-551.

Prager, K, and U.J. Nagel. 2008. Participatory decision making on agri-environmental programmes: A case study from Sachsen-Anhalt (Germany). Land Use Policy 25(1): 106-115.

Reed, M. S., A. Graves, N. Dandy, H. Posthumus, K. Hubacek, J. Morris, C. Prell, C. H. Quinn, and L. C. Stringer. 2009. Who's in and why? A typology of stakeholder analysis methods for natural resource management. Journal of Environmental Management 90 (5): 1933-1949.

Reig-Martínez, E. 2007. Fundamentos Económicos de la Multifuncionalidad. In La Multifuncionalidad de la Agricultura Española, 19-39. Madrid: Ministerio de Agricultura, Pesca y Alimentación y Eumedia. , .

Renting, H., W. A. H. Rossing, J. C. J. Groot, J. D. van der Ploeg, C. Laurent, D. Perraud, D. J. Stobbelaar, and M. K. van Ittersum. 2009. Exploring multifunctional agriculture. A review of conceptual approaches and prospects for an integrative transitional framework. Journal of Environmental Management 90: 112-123.

Romero, C. 1996. Análisis de las Decisiones Multicriterio, vol. 14. Madrid: Isdefe.

Saaty, T. L. 1977. A scaling method for priorities in hierarchical structures. Journal of Mathematical Psychology 15 (3): 234-281.

Saaty, T. L., and L. G. Vargas. 2005. The possibility of group welfare functions. International Journal of Information Technology \& Decision Making 4 (2): 167-176.

Sae-Lim, P., H. Komen, A. Kause, J. A. van Arendonk, A. J. Barfoot, K. E. Martin, and J. E. Parsons. 2011. Defining desired genetic gains for rainbow trout breeding objective using analytic hierarchy process. Journal of Animal Science 90 (6): 1766-1776.

Sayadi, S., M. C. González, and J. Calatrava-Requena. 2004. Estudio de las preferencias por los elementos agrarios del paisaje mediante los métodos de Análisis Conjunto y Valoración Contingente. Economía Agraria y Recursos Naturales 4 (7): 135-151.

Schmitz, K., P.M. Schmitz, and T.C. Wronka. 2003. Bewertung von Landschaftsfunktionen mit Choice Experiments Valuation of landscape functions using choice experiments. Agrarwirtschaft 52 (8): 379-389. 
van Zanten, B. T., P. H. Verburg, M. Espinosa, S. Gómez-y-Paloma, G. Galimberti, J. Kantelhardt, M.

2 Kapfer, M. Lefebvre, R. Manrique, A. Piorr, et al. 2014. European agricultural landscapes, common agricultural policy and ecosystem services: a review. Agronomy for Sustainable Development 34 (2): 309-325.

Vaz, E., T. De Noronha, and P. Nijkamp. 2014. Exploratory Landscape Metrics for Agricultural Sustainability. Agroecology and Sustainable Food Systems 38 (1): 92-108.

Welp, M., A. de la Vega-Leinert, S. Stoll-Kleemann, and C. C. Jaeger. 2006. Science-based stakeholder dialogues: Theories and tools. .Global Environmental Change 16 (2): 170-181.

Whitmarsh, D., and M. G. Palmieri. 2009. Social acceptability of Marine Aquiculture: The use of surveybased methods for eliciting public and stakeholders preferences. Marine Policy 33: 452-457.

Zasada, I. 2011. Multifunctional peri-urban agriculture-A review of societal demands and the provision of goods and services by farming. Land Use Policy 28 (4): 639-648. 

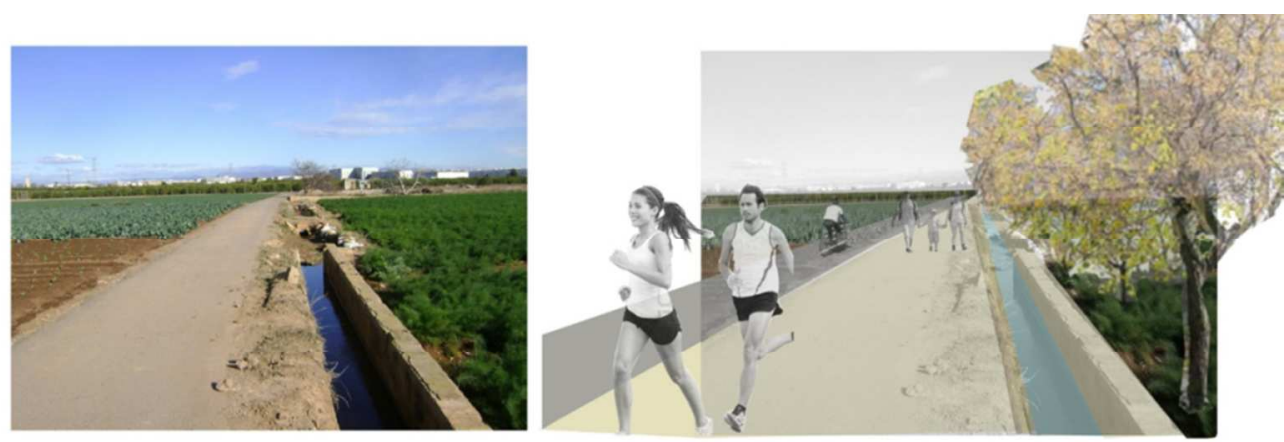

Figure 1: Proposals for the recreational use of the Huerta de Valencia 


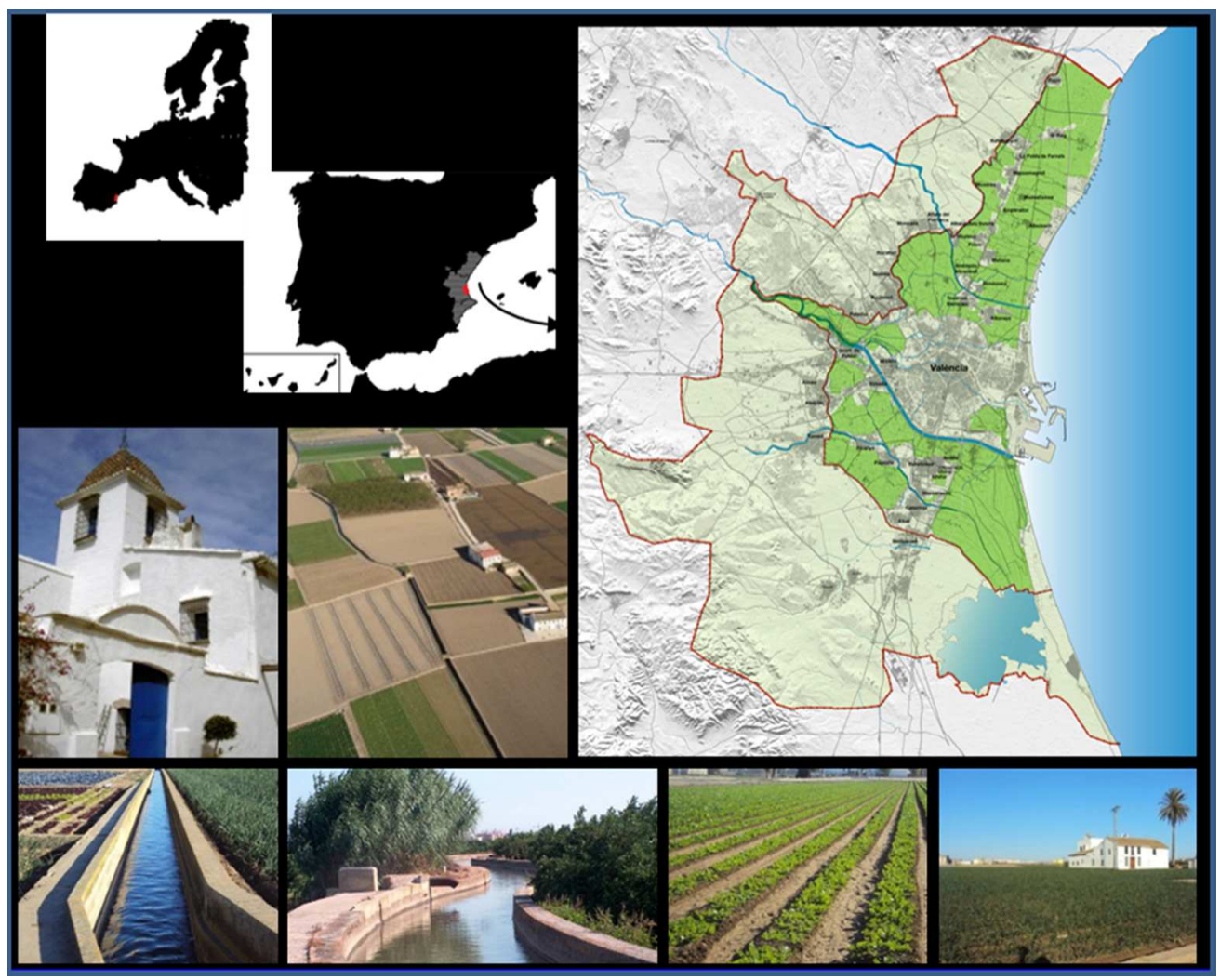

Figure 2 


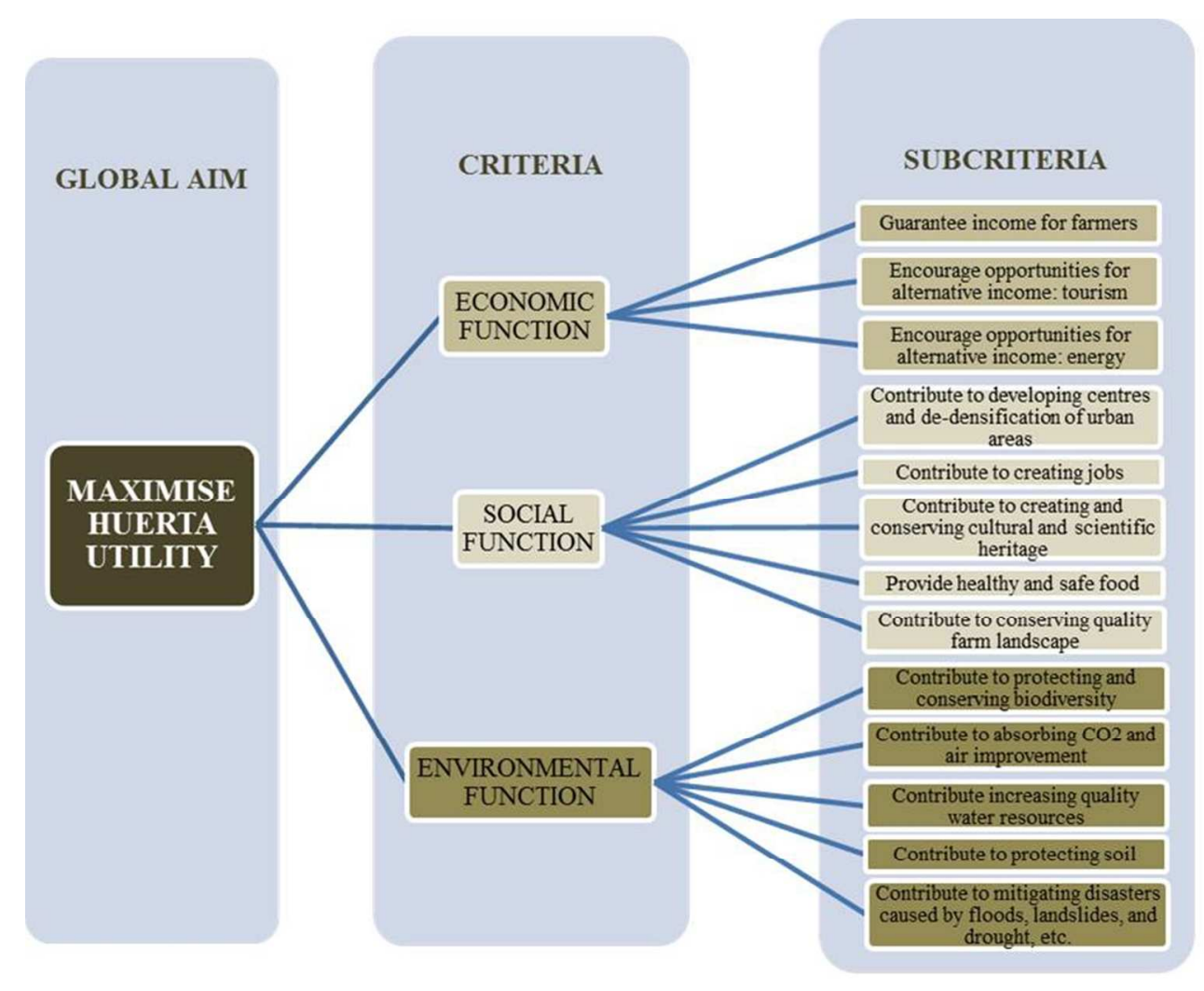

Figure 3: Hierachy

$185 \times 146 \mathrm{~mm}(131 \times 131 \mathrm{DPI})$ 


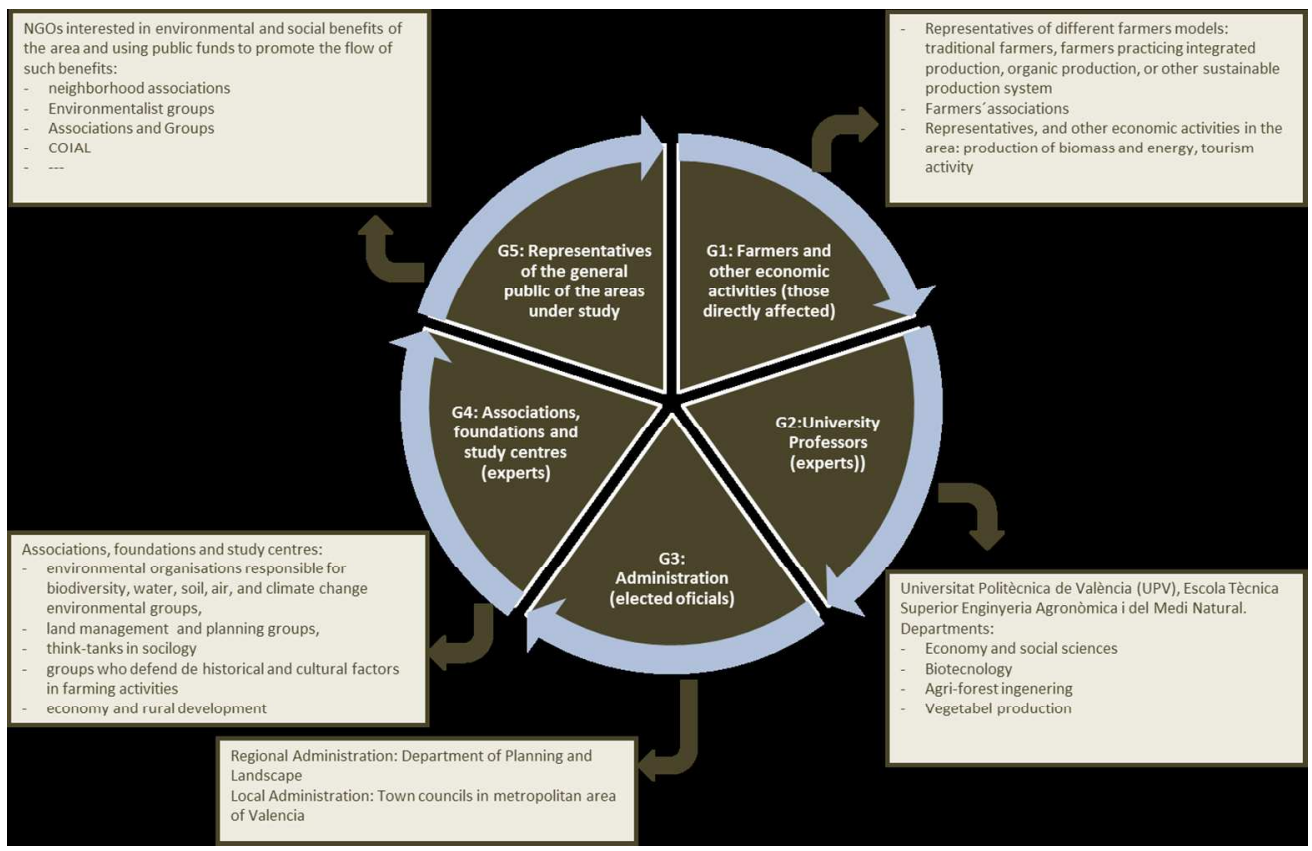

Figure 4 


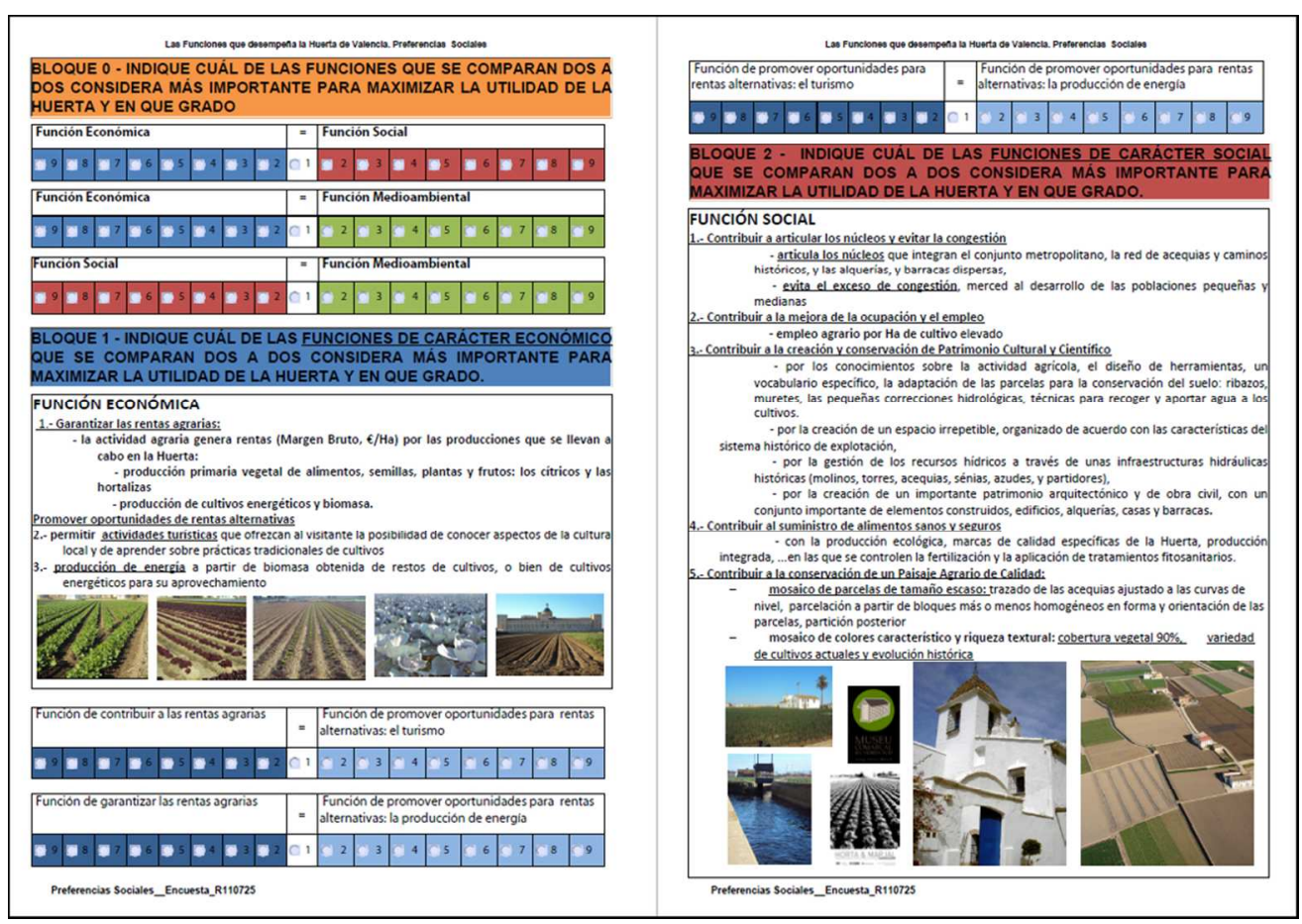

Figure 5 
1 Integrating social preferences analysis for multifunctional

2 peri-urban farming into planning. An application of multi-

3 criteria analysis techniques and stakeholders.

4 
Table 1: Peri-urban agricultural system functions, goods and services

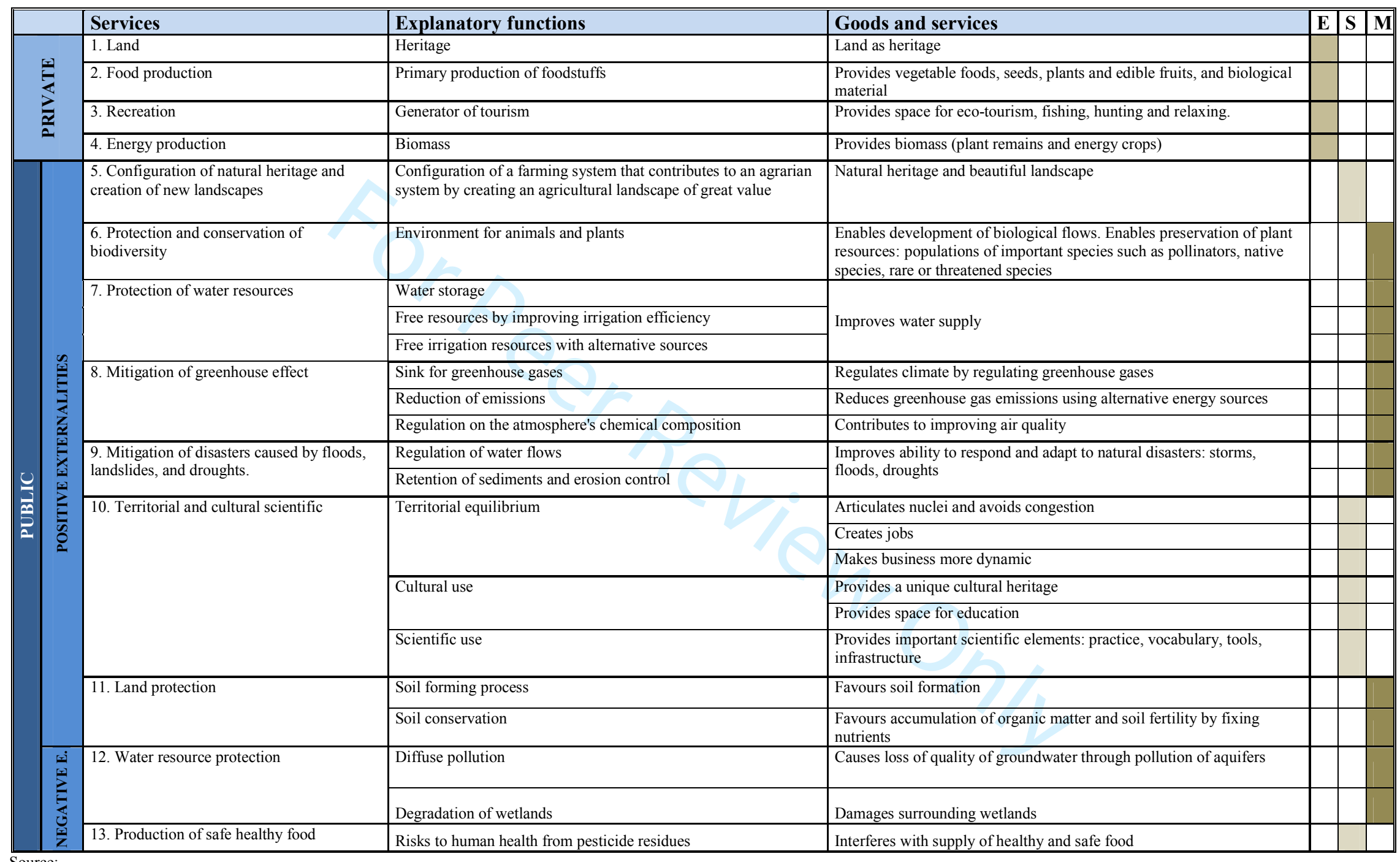


Table 2: Stakeholder summary

\begin{tabular}{|c|c|c|c|c|c|}
\hline & & $\ddot{\varpi}$ & $\approx$ & ○゚ & $\frac{\frac{2}{200}}{2}$ \\
\hline \multicolumn{2}{|c|}{ G1: ECONOMIC SECTOR (those directly affected) } & 129 & 23 & $17,83 \%$ & $16,43 \%$ \\
\hline Urban farming & Hort de Perot, Hort de Carme, Huertos del Turia, ... & 14 & 1 & & \\
\hline Municipal farming & Godella, Massamagrell, Benimaclet, Aldaia, Picanya, ... & 6 & 0 & & \\
\hline Solidarities farming & Cárirtas. Avenida de la Plata, CEM Julià Paterna, ... & 5 & 0 & & \\
\hline Farmers & Martí, Vicent Marco, Terra i Salut, ... & 12 & 11 & & \\
\hline $\begin{array}{l}\text { Farmers of Organic } \\
\text { Production }\end{array}$ & $\begin{array}{llllll}\text { El Coscollar, Horts } & \text { Eco-urbans, Sembra en } & \text { Saó, } \\
\text { Ecomediterránea }\end{array}$ & 5 & 5 & & \\
\hline $\begin{array}{l}\text { Other activities in the } \\
\text { area }\end{array}$ & $\begin{array}{l}\text { Afrasa, Horta Viva, Terra i Xufa, Naturalgar, Horta directa, } \\
\text { Terra i salut, ... }\end{array}$ & 57 & 4 & & \\
\hline \multirow[t]{4}{*}{ Farmers' associations } & Asociación Valenciana de Agricultores, Fumava & 12 & 0 & & \\
\hline & $\begin{array}{l}\text { La Unió, Fundació Institut Valencià d'Investigació i Formació } \\
\text { Agroambiental }\end{array}$ & 15 & 2 & & \\
\hline & Asociació de Llauradors de Puçol & 1 & 0 & & \\
\hline & $\begin{array}{l}\text { ConsejoRegulador de la Denominación de Origen Chufa de } \\
\text { Valencia }\end{array}$ & 2 & 0 & & \\
\hline \multicolumn{2}{|c|}{ G2: SCIENTIFIC SECTOR (experts) } & 88 & 32 & $36,36 \%$ & $22,86 \%$ \\
\hline $\begin{array}{l}\text { Universitat politècnica } \\
\text { deValència }\end{array}$ & $\begin{array}{l}\text { University professors in Departments: Economy and Social } \\
\text { Sciences, Biotechnology, Agricultural Engineering, Plant } \\
\text { Production }\end{array}$ & 88 & 32 & & \\
\hline \multicolumn{2}{|c|}{ G3: ADMINISTRATION (elected officials) } & 205 & 39 & $19,02 \%$ & $27,86 \%$ \\
\hline $\begin{array}{l}\text { Regional } \\
\text { Administration }\end{array}$ & Department of Planning and Landscape & 41 & 12 & & \\
\hline Local Administration & City Councils Metropolitan Area of Valencia & 164 & 27 & & \\
\hline \multicolumn{2}{|c|}{ G4: ASSOCIATIONS, FOUNDATIONS AND STUDY CENTRES (experts) } & 105 & 22 & $20.95 \%$ & $15,71 \%$ \\
\hline Biodiversity & Institut Cavanilles de Biodiversitat, Llavors d'Ací, ... & 37 & 1 & & \\
\hline Sociology & $\begin{array}{l}\text { Instituto Interuniversitario de Desarrollo Local, Fundación } \\
\text { Ceps... }\end{array}$ & 19 & 5 & & \\
\hline $\begin{array}{l}\text { Economy and Rural } \\
\text { development }\end{array}$ & $\begin{array}{l}\text { International Centre of Research and Information on the } \\
\text { Public, Social and Cooperative Economy, Applied Economics } \\
\text { Department (Universitat de València) }\end{array}$ & 8 & 6 & & \\
\hline Water & Seiasa, CEV-UPV & 9 & 0 & & \\
\hline Geography & Col.lectiuy de geografs, Institut d'Estudis Valencians, & 12 & 4 & & \\
\hline Planning & $\begin{array}{l}\text { Institut del Territori, Departament of Urbanism (UPV), } \\
\text { Institute of Social Economy and Cooperation }\end{array}$ & 5 & 2 & & \\
\hline Heritage & $\begin{array}{l}\text { Fundació Assut, Centre d'Estudios de L'Horta Nord, PAISAR, } \\
\text { Research Group on Lansdcape and Architecture }\end{array}$ & 15 & 4 & & \\
\hline \multicolumn{2}{|c|}{ G5: Representatives of the CIVIL SOCIETY AND THE GENERAL PUBLIC } & 135 & 24 & $17,78 \%$ & $17,14 \%$ \\
\hline $\begin{array}{l}\text { Neighbourhood } \\
\text { associations }\end{array}$ & $\begin{array}{l}\text { Federación de AAVV de Valencia, AV Barrrio San José, Gent } \\
\text { del Carme, Patraix, }\end{array}$ & 55 & 5 & & \\
\hline $\begin{array}{l}\text { Environmentalists } \\
\text { groups }\end{array}$ & Acció Ecologista Agró, La Colla, Ecologistas en acción,... & 5 & 1 & & \\
\hline $\begin{array}{l}\text { Associations and } \\
\text { Groups }\end{array}$ & Per l'Horta, Sembra en Saó, Repensem 1'Horta, ... & 73 & 16 & & \\
\hline \multicolumn{2}{|c|}{ Professional Associations: Colegio Oficial de Ingenieros Agrónomos } & 2 & 2 & & \\
\hline \multicolumn{2}{|c|}{ TOTAL of stakeholder surveys } & & 140 & & $100,00 \%$ \\
\hline
\end{tabular}


Table 3: Weights of the subcriteria according to stakeholders (AIJ)

\begin{tabular}{|c|c|c|c|c|c|c|c|c|c|c|c|c|c|}
\hline $\begin{array}{c}\text { GENERIC FUNCTIONS } \\
\text { (CRITERIA) }\end{array}$ & \multicolumn{3}{|c|}{$\begin{array}{l}\text { ECONOMIC } \\
\text { FUNCTIONS }\end{array}$} & \multicolumn{5}{|c|}{ SOCIAL FUNCTIONS } & \multicolumn{5}{|c|}{ ENVIRONMENTAL FUNCTIONS } \\
\hline $\begin{array}{c}\text { EXPLANATORY FUNCTIONS } \\
\text { (SUBCRITERIA) }\end{array}$ & wEI & wT & wEng & wCity & wJob & $\mathrm{wC} \& \mathrm{~S}$ & wSF & wAL & wBIOdv & wSCO2 & $\mathrm{wQH} 2 \mathrm{O}$ & wPrtSoil & wRdist \\
\hline Aggregation of stakeholders & $52.68 \%$ & $28.94 \%$ & $18.38 \%$ & $10.31 \%$ & $21.09 \%$ & $16.48 \%$ & $29.69 \%$ & $22.44 \%$ & $25.63 \%$ & $20.43 \%$ & $12.94 \%$ & $22.78 \%$ & $18.22 \%$ \\
\hline G1: Farmers and others & $66.14 \%$ & $23.43 \%$ & $10.43 \%$ & $9.96 \%$ & $31.25 \%$ & $11.04 \%$ & $35.24 \%$ & $12.52 \%$ & $25.90 \%$ & $27.64 \%$ & $13.83 \%$ & $15.98 \%$ & $16.65 \%$ \\
\hline G2: University professors & $50.57 \%$ & $29.37 \%$ & $20.06 \%$ & $10.09 \%$ & $22.93 \%$ & $14.14 \%$ & $28.02 \%$ & $24.81 \%$ & $21.95 \%$ & $21.91 \%$ & $14.22 \%$ & $25.00 \%$ & $16.91 \%$ \\
\hline G3: Administration & $48.79 \%$ & $30.84 \%$ & $20.36 \%$ & $8.88 \%$ & $24.54 \%$ & $15.49 \%$ & $26.15 \%$ & $24.94 \%$ & $25.19 \%$ & $19.20 \%$ & $12.41 \%$ & $23.85 \%$ & $19.35 \%$ \\
\hline G4: Associations, foundations ... & $45.50 \%$ & $38.40 \%$ & $16.10 \%$ & $9.66 \%$ & $9.57 \%$ & $27.88 \%$ & $21.28 \%$ & $31.62 \%$ & $29.43 \%$ & $12.50 \%$ & $12.82 \%$ & $28.14 \%$ & $17.11 \%$ \\
\hline G5: General public of the area & $49.60 \%$ & $22.60 \%$ & $27.79 \%$ & $11.13 \%$ & $20.40 \%$ & $14.83 \%$ & $34.53 \%$ & $19.11 \%$ & $24.56 \%$ & $22.95 \%$ & $10.88 \%$ & $21.41 \%$ & $20.19 \%$ \\
\hline
\end{tabular}

E: economic. S: social. EM: environmental. EI: economic income from sales of farm products. T: rural tourism business. Eng: biomass production to generate energy to sell. City: Favours the link and helps avoid city congestion. Job: Offers job opportunities. C\&S: Create goods of cultural and scientific interest. SF: Produces healthy, safe foods. AL: attractive agrarian landscape; BIOdv: Promotes biodiversity. $\mathrm{SCO}_{2}$ : Carbon sequestration. $\mathrm{QH}_{2} \mathrm{O}$ : quality water. PrtSoil: Protects soil. Rdist: reduces effects of disasters caused, etc. 
1

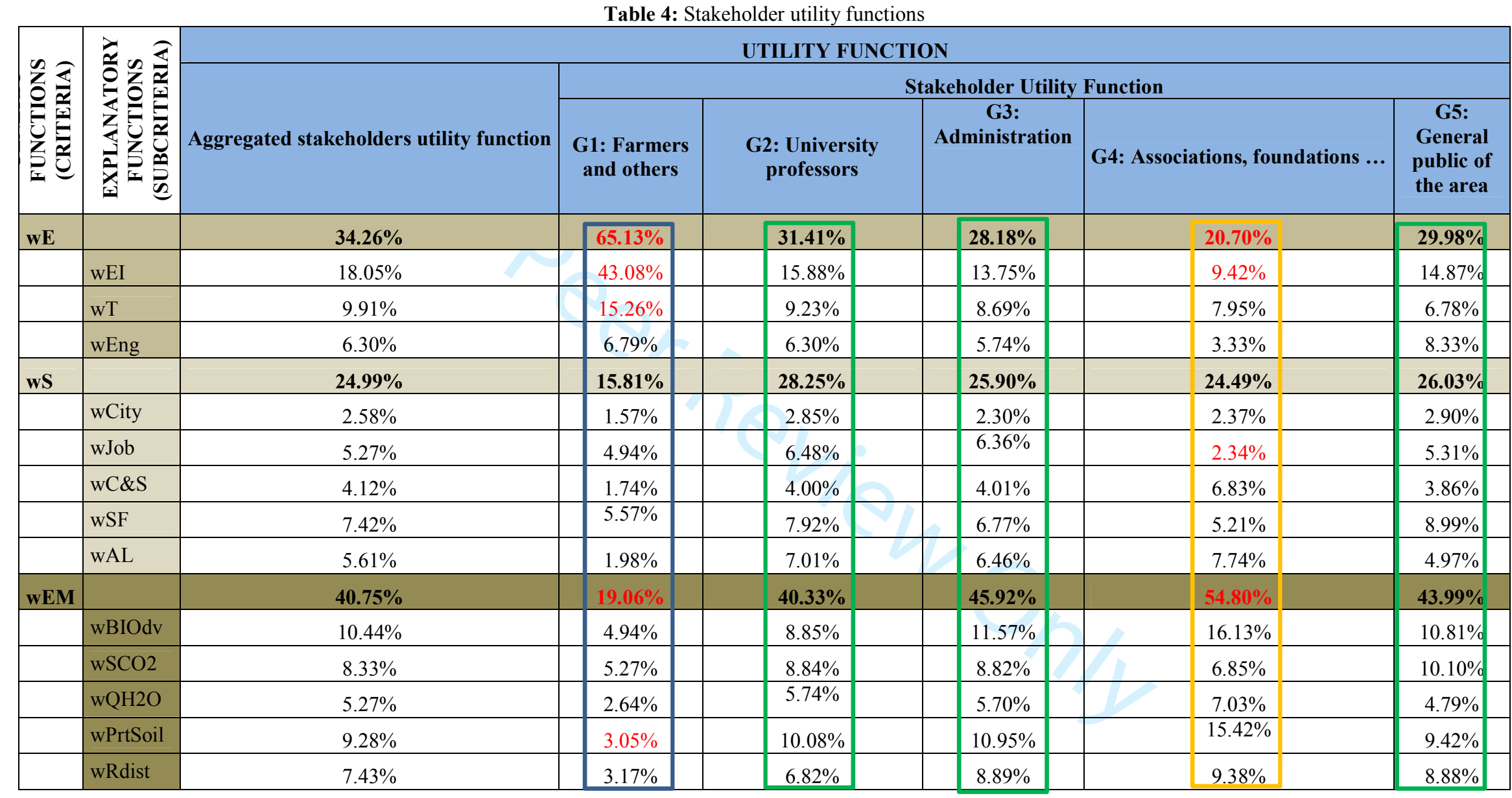


Table 5: Disaggregation of stakeholders

Farmers

Farmers (Integrated agricultural production)

University professors

Representative of bodies managing water resources

Employers or their representatives with activities in the farmland: touristic, industrial and nurseries

Representatives of metropolitan neighbourhood associations

Local administrators from the metropolitan area

Regional land use administrators

Environmental groups

Members of associations, foundations and study centres

Representatives of organisations that bring together private companies that allocate resources to land stewardship

Non-profit organisations interested in environmental and social benefits of the area using public funds to encourage such benefits

3 
Dear reviewer,

I am sending AGROECOLOGY AND SUSTAINABLE FOOD SYSTEMS our manuscript entitled "Integrating social preferences analysis for multifunctional peri-urban farming in planning. An application by multi-criteria analysis techniques and stakeholders".

We thank you for their comments and suggestions, which we understand will improve the manuscript quality, and for this reason we have taken them into account. We have made the revisions for our paper, and we send you now, the manuscript considered your comments. We did not want to refute any point from comments. We attached a list of changes which was been raised in our revised manuscript.

Thank you very much for your care and attention.

We wait for a decision on our manuscript as soon as possible.

Sincerely yours

\section{ANSWERS TO REVIEWERS' COMMENTS}

\begin{tabular}{|c|c|c|}
\hline \multirow{6}{*}{. } & COMMENTS & CHANGES \\
\hline & $\begin{array}{l}\text { The topic of the paper is surely interesting } \\
\text { and novel and could find some interested } \\
\text { readership with Agroecology and } \\
\text { Sustainable Food Systems. However, } \\
\text { therefore, I would suggest to strengthen } \\
\text { the system approach in the paper. }\end{array}$ & \\
\hline & $\begin{array}{l}\text { First of all, and a bit more generally, I find } \\
\text { the manuscript not really carefully } \\
\text { prepared: The text is not well structured } \\
\text { and has plenty of typos and mistakes. }\end{array}$ & $\begin{array}{l}\text { We have taken into account the questions suggested } \\
\text { by reviewers and we have rewritten the manuscript. }\end{array}$ \\
\hline & $\begin{array}{l}\text { Line numbers end at page } 5 \text {. Table and } \\
\text { figures do not really comply with } \\
\text { international journal standards. This all } \\
\text { requires extensive revisions }\end{array}$ & $\begin{array}{l}\text { We have added line numbers to every page. } \\
\text { We have revised the tables. }\end{array}$ \\
\hline & $\begin{array}{l}\text { Unclear value of figure } 1 \text {. Seems not } \\
\text { necessary }\end{array}$ & $\begin{array}{l}\text { The aim of figure } 1 \text { is to show an alternative use for } \\
\text { leisure in the Huerta de Valencia. It is possible to take } \\
\text { it out without affecting the substance of the } \\
\text { manuscript in any way at all. We leave it up to the } \\
\text { editor. }\end{array}$ \\
\hline & $\begin{array}{l}\text { Format / language issues in the text and } \\
\text { reference list(e.g. use of Spanish language }\end{array}$ & $\begin{array}{l}\text { All the references have been reviewed and formatted } \\
\text { according to the format of the journal. }\end{array}$ \\
\hline
\end{tabular}


and format)

Actual language mistakes, e.g. p.3, I.12

The text has been revised by a native English reviser.

(improve), I.23 (London), p.4, I.17

(European Commission), foundations, comma/point issues... etc. Check for language is extremely necessary

Table 1: Why do you start with "0." Land?

We have changed the numbering.

Why not " 1. ".

I have doubts of the objective of the paper to "improve the methodology for public participation". This sounds extremely applied and more like a guidance for planners. But this is it clearly not. In my opinion the paper pursues an academic exercise assessing a public opinion in a specific case, but without any methodological development to be applied in a non-academic context.

Planning processes in the field of managing natural resources and the environment (generally complex and multidimensional) have become participatory in most developed countries. Planners incorporate various principles, mechanisms, programmes, and effective procedures for public participation in the planning process. As a result of European legislation and the European Landscape Convention, this approach is already a fact in European urban planning, specifically in relation to interventions affecting the landscape. In addition, environmental conflicts regarding water are often very complex and have recently been addressed with mechanisms for public participation in the Water Framework Directive. In countries such as the United States, Australia and Spain, significant efforts to create opportunities for participation in policy decisions on natural resources have been made (especially regarding forests). In peri-urban systems. planning processes can be difficult and delicate. The complexity arises from the fact that there are many factors to be considered and, consequently, many stakeholders may be involved in the decision process, often with conflicts of interest. This manuscript is an academic exercise whose objective is twofold: firstly, to obtain public opinion on a specific case, and secondly, to develop the multi-criteria methodology, and particularly the methodology of paired comparisons in the version by Saaty (the AHP) as an alternative to be used in the study of social preferences. We propose using it through a digital format, sent electronically to specific stakeholders. This format allows better access and higher 


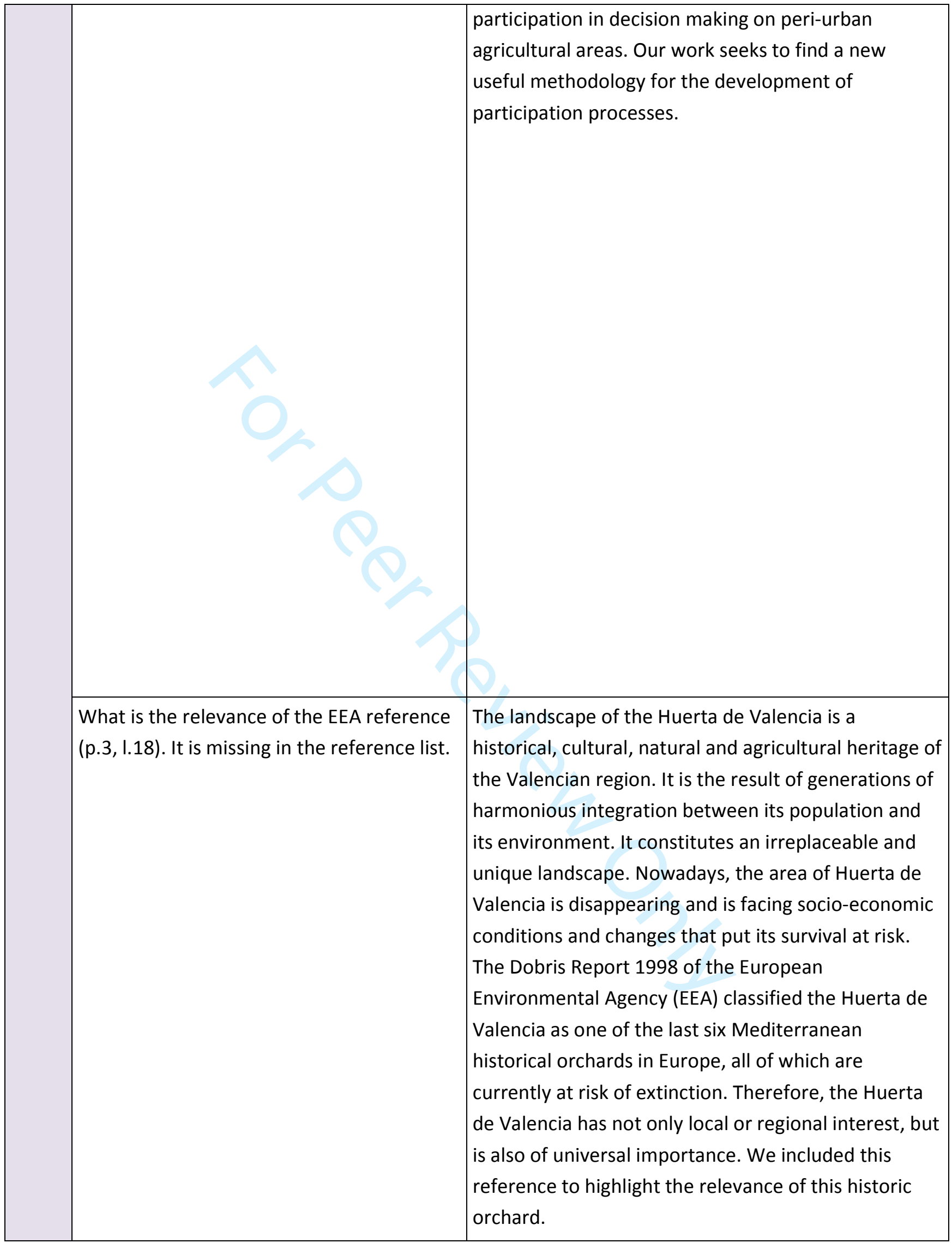




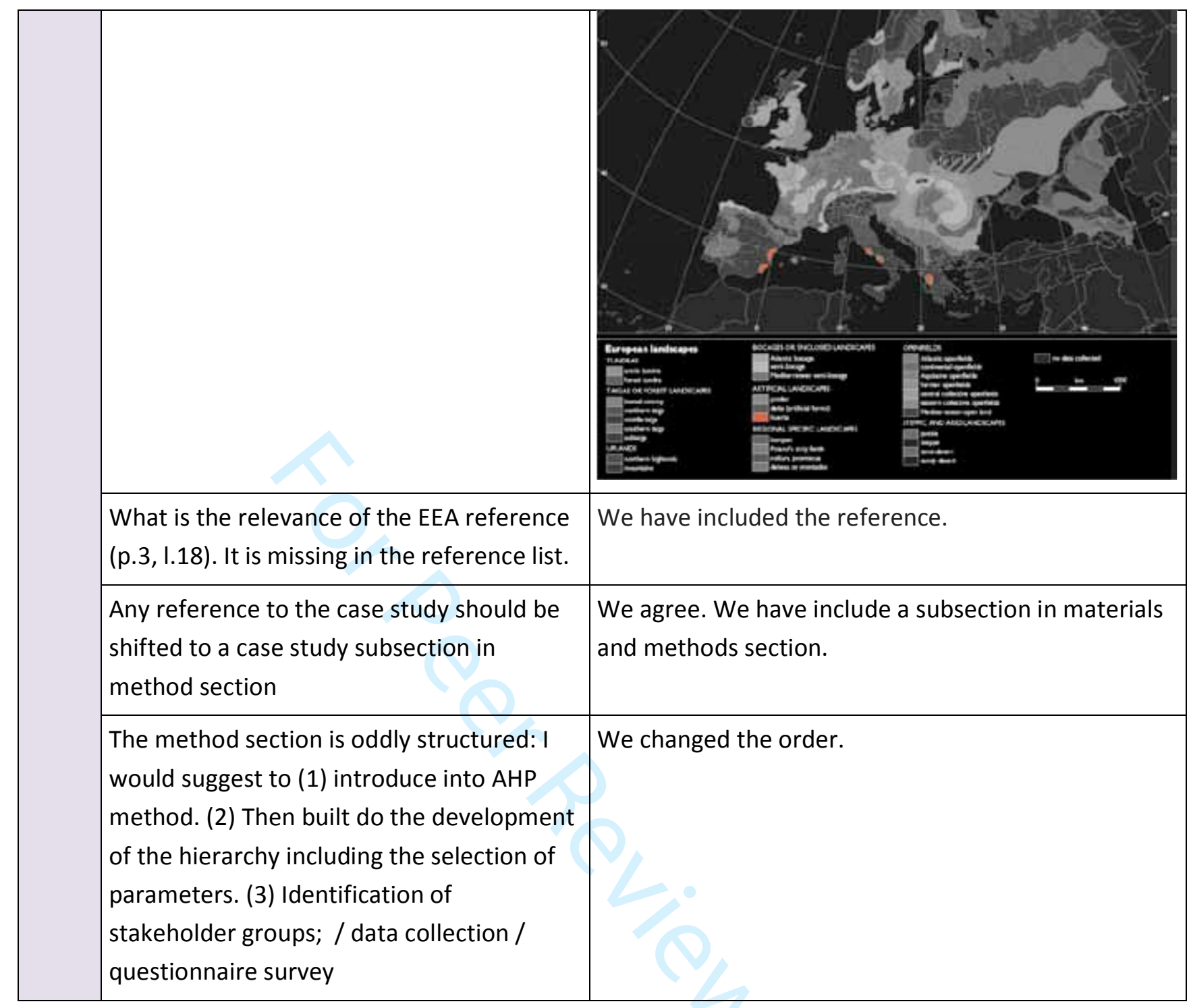


P.4, I.1-P.5,I.5: It is a bit unclear, how exactly you came up with these criteria.

Multi-functionality (MFA) was first introduced at the Summit of Rio de Janeiro in 1992 (Reig, 2007), as an important element in the evaluation of agricultural policy. The European Commission has subsequently introduced this concept in the international political scene, incorporating it in the CAP and in the World Trade Organization (WTO) negotiations. It is a conceptual framework in which farming is seen as part of a broader concept that includes functions relating to the care of the environment and landscape, conservation of cultural heritage, improving aspects of social balance, and the provision of recreational services. The existence of these other (non-productive) functions of farming that generate non-commercial goods and services for which there is a social demand in developed countries is the basis for justifying the protection of farming. Some authors defend that MFA has been widely recognized in periurban areas, providing an approach that strengthens and modernizes peri-urban agriculture (Chiara 2015) (Rogge and Corsi 2015) (Filippini 2014) (Zasada 2013). Based on the classification proposed by Abler (2001) for these goods and services, and taking into account the proposals of various authors (Kallas et al. 2007; Goméz-Limón et al. 2007; Gómez-Limón et al 2008; Renting et al. 2009; Zasada 2011; Ivesa and Kendalb 2013), we created a descriptive approach for the multi-functionality of peri-urban agricultural systems (see Table 1).

Why do you have basically two expert groups with researchers from universities, etc.? What is the logic behind this?
On the one hand, there are many studies on the Huerta de Valencia and this area has been analysed by different University professors -such as historians, economists, geographers, architects, heritage specialists, hydraulic engineers specialised in heritage, as well as specialists in farming infrastructure in general - who carry out research at field, farm and landscape levels and on crops and cropping systems. , On the other hand, there are some associations, foundations, study centres, environmental organisations, climate change environmental groups, land management groups and think-tanks which are supported by civil society and that defend the value of historical and cultural factors 


\begin{abstract}
20lons
Generally, the use of researchers as stakeholder are a bit strange, as they do not represent a societal interest. However, you say that they are important "for defining potential and operating alternative and future scenarios". Where is this been done? In this study? I am missing this in the
\end{abstract} text.

First part of the result section (p.10, table 2, partly p.12) should be moved to the collection subsection, in materials and methods method section, as you describe the empirical method and not the results.

The actual results (tab. 3, 4, fig.6) require We have moved the text and completed it. some explanation in the text, which is completely missing. What are the main findings? What do you want to draw attention to? I don't want to only look at the table and pick the numbers myself. For instance, I find it quite interesting that the social dimension is pretty underrepresented throughout all groups, despite you are looking at a peri-urban space.

Fig. 6 is redundant with Tab. 4 and can be excluded.

The discussion section starts with a description of the results. This should be moved to the results section.

Otherwise the discussion section lacks other important issues, e.g. comparison We have changed the text to include the reviewer's study, applicability in other case studies? Generally, the analytical "depth" is not very high. The discussion remains at the surface without elaborating the lines of argumentation.

Who do you come up with these different farming systems? Is this based on comments.

We have excluded it.

We have moved it.

They are based on Spanish regulations that differentiate between different levels of eco- 


\begin{tabular}{|l|l|l|}
\hline literature? & compatible productions. \\
\cline { 2 - 3 } & $\begin{array}{l}\text { What is the meaning of table 5? Can be } \\
\text { excluded. }\end{array}$ & $\begin{array}{l}\text { A division of the groups that could be very useful in } \\
\text { future work to obtain more homogeneous groups, } \\
\text { with more consistent added priorities. }\end{array}$ \\
\hline $\begin{array}{l}\text { I think your discussion of the "participation } \\
\text { process" from p.16, last paragraph on, is } \\
\text { strangely disconnected from the rest of the } \\
\text { text. What have we learned about } \\
\text { participation in your study? Why do you } \\
\text { come up with the web-tool discussion } \\
\text { (p.17)? Where is the link to your study? }\end{array}$ & Wut the link to our study is not available right now. \\
\hline
\end{tabular}


Dear reviewer,

I am sending AGROECOLOGY AND SUSTAINABLE FOOD SYSTEMS our manuscript entitled "Integrating social preferences analysis for multifunctional peri-urban farming in planning. An application by multi-criteria analysis techniques and stakeholders".

We thank you for their comments and suggestions, which we understand will improve the manuscript quality, and for this reason we have taken them into account. We have made the revisions for our paper, and we send you now, the manuscript considered your comments. We did not want to refute any point from comments. We attached a list of changes which was been raised in our revised manuscript.

Thank you very much for your care and attention.

We wait for a decision on our manuscript as soon as possible.

Sincerely yours

\section{ANSWERS TO REVIEWERS' COMMENTS}

\begin{tabular}{|c|c|c|}
\hline \multirow{6}{*}{ 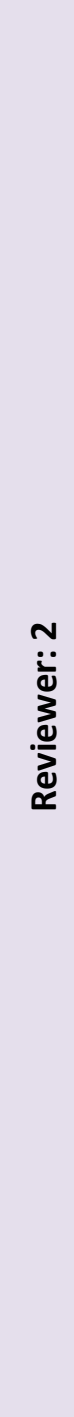 } & $\begin{array}{l}\text { Very interesting and original paper, with an } \\
\text { important contribution to consultation and } \\
\text { decision making in planning peri-urban } \\
\text { farming. } \\
\text { I am not a specialist of multi criteria } \\
\text { analysis, so, even if I have understood the } \\
\text { logics and results of the analysis I cannot } \\
\text { say if other approaches, always in multi } \\
\text { criteria analysis could be better, if they } \\
\text { have already been explored and applied. }\end{array}$ & \\
\hline & $\begin{array}{l}\text { there are several typos in many sentences } \\
\text { (es. page } 1 \text { hydraulic row } 16 \text {, Functions, } \\
\text { row } 31 . . \text { ) The paper requires careful } \\
\text { reading, and even the English form can be } \\
\text { improved in some steps }\end{array}$ & The text has been revised by a native English reviser. \\
\hline & - Some sentences are not clear. & The text has been revised by a native English reviser. \\
\hline & $\begin{array}{l}\text { Page } 2 \text {, rows 3-4-5. Clarify and improve the } \\
\text { English form }\end{array}$ & The text has been revised by a native English reviser. \\
\hline & $\begin{array}{l}\text { Page } 4 \text { rows } 15-16 \text {... "each of them has } \\
\text { classified itself"... Is it correct? Better } \\
\text { clarify }\end{array}$ & The text has been revised by a native English reviser. \\
\hline & $\begin{array}{l}\text { Page } 4-5 \text { rows } 35-1 \text { : I guess that something } \\
\text { is missing }\end{array}$ & The text has been revised by a native English reviser. \\
\hline
\end{tabular}


Here I have some doubts, more on the criteria on which the taxonomy has been done. In particular 9. Territorial equilibrium that has goods and services as "creates jobs" and "makes business more dynamic". In reality the creation of jobs could be applied almost in all the services, and dynamism of business too. Don't you think so?
Definitely, but in relation to "Territorial equilibrium" it can be considered as a direct result. 